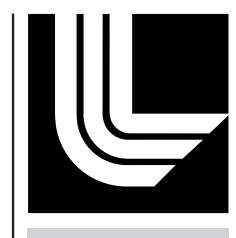

LAWRENCE LIVERMORE NATIONAL LABORATORY

Banyan 1.7 Compliance Manager Rough Guide

Version 1.4

R. H. Barter

September 6, 2005 


\section{Banyan 1.7 \\ Compliance Manager \\ Rough Guide \\ Version 1.4}

September 6, 2005

UCRL-TR-215054 
This document was prepared as an account of work sponsored by an agency of the United States Government. Neither the United States Government nor the University of California nor any of their employees, makes any warranty, express or implied, or assumes any legal liability or responsibility for the accuracy, completeness, or usefulness of any information, apparatus, product, or process disclosed, or represents that its use would not infringe privately owned rights. Reference herein to any specific commercial product, process, or service by trade name, trademark, manufacturer, or otherwise, does not necessarily constitute or imply its endorsement, recommendation, or favoring by the United States Government or the University of California. The views and opinions of authors expressed herein do not necessarily state or reflect those of the United States Government or the University of California, and shall not be used for advertising or product endorsement purposes.

This work was performed under the auspices of the U.S. Department of Energy by University of California, Lawrence Livermore National Laboratory under Contract W-7405-Eng-48.

Contact information:

R. H. Barter Lawrence Livermore National Laboratory

P.O. Box 808

Livermore, California, 94550

$925-422-5150$ 


\section{Table of Contents}

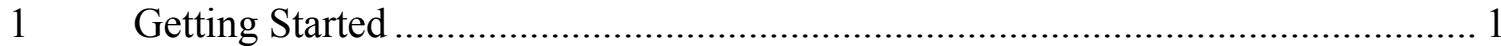

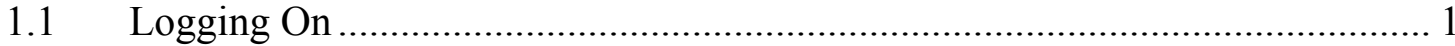

1.2 User Name and Password …………………............................................. 2

2 Document Storage Area .............................................................................. 4

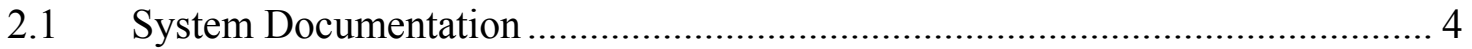

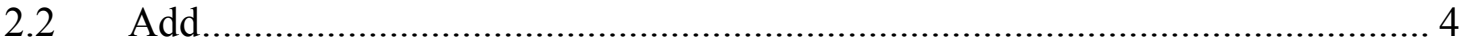

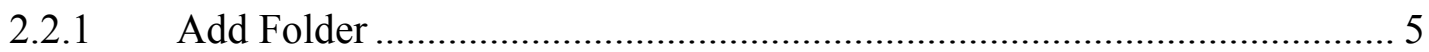

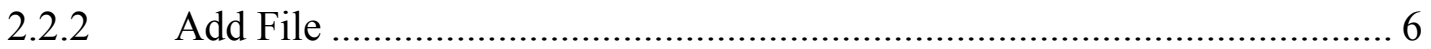

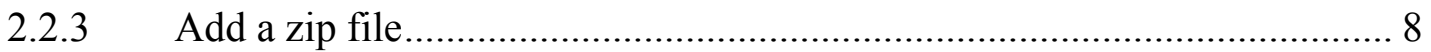

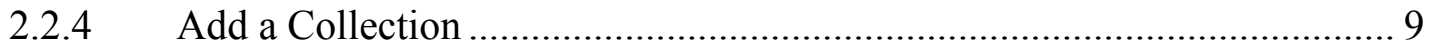

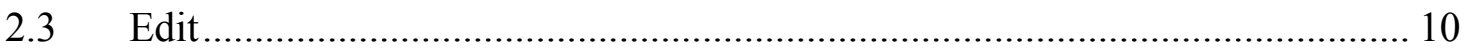

2.3.1 Title and Description........................................................................... 10

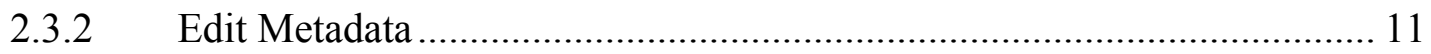

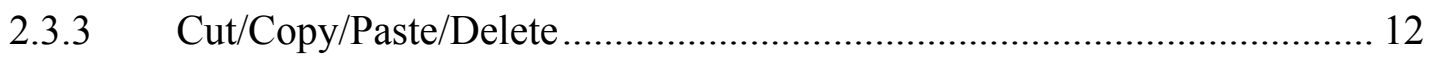

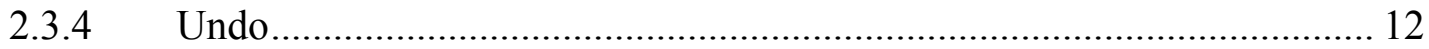

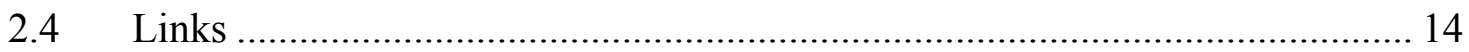

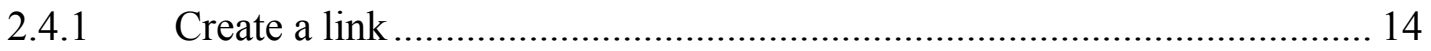

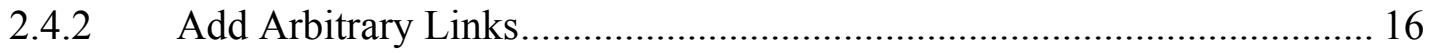

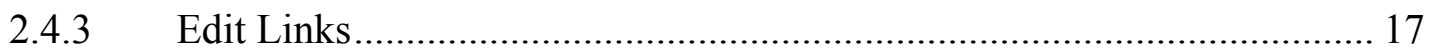

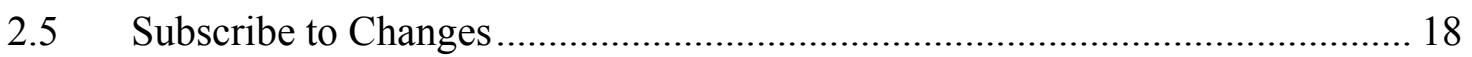

2.5.1 Add a Subscription........................................................................ 18

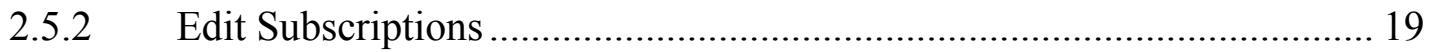

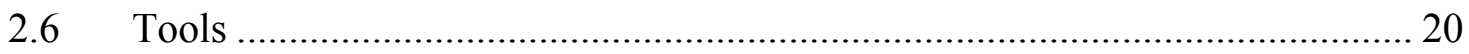

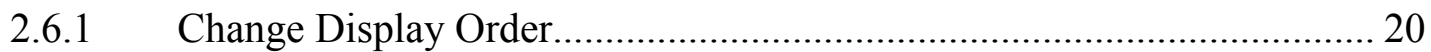

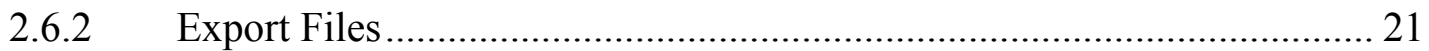

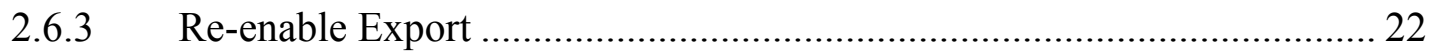

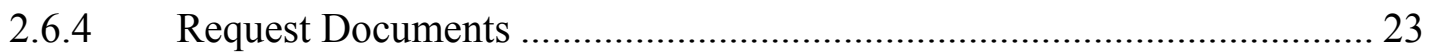

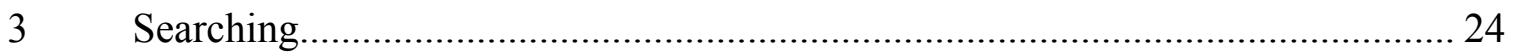

3.1 Quick Search of Documents ...................................................................... 24

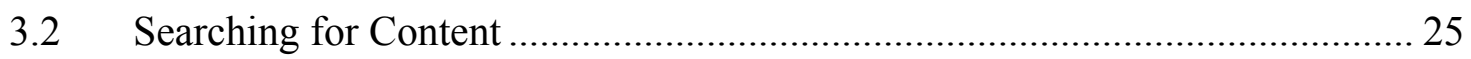

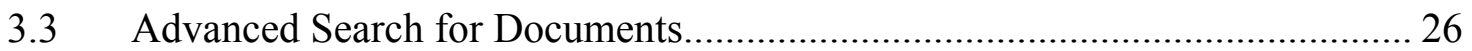

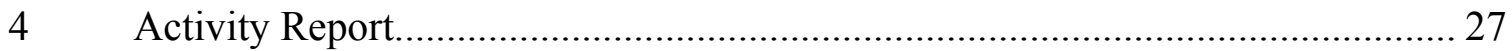

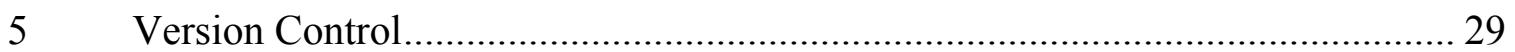

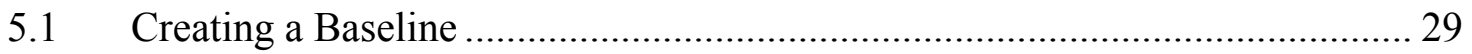

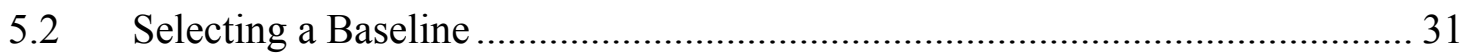


5.3 Linking a Document to the Baseline.......................................................... 31

5.4 Viewing Proposed Changes to a Baseline ................................................... 32

5.5 Submitting a Baseline .............................................................................. 33

5.6 Approving a Baseline - Requires Reviewer Role.......................................... 33

5.7 Viewing the Contents of a Baseline............................................................. 34

5.8 Rejecting a Baseline - Requires Reviewer Role........................................... 35 


\section{Getting Started}

\subsection{Logging On}

If you are using Banyan from a sever, then your URL will be provided by your system administrator. Please fill in the URL in the space provided. If you are using a version of Banyan that you installed on your workstation from the setup.exe file and you have accepted all of the default settings, then your URL will be http://localhost:8080/Banyan.

URL:

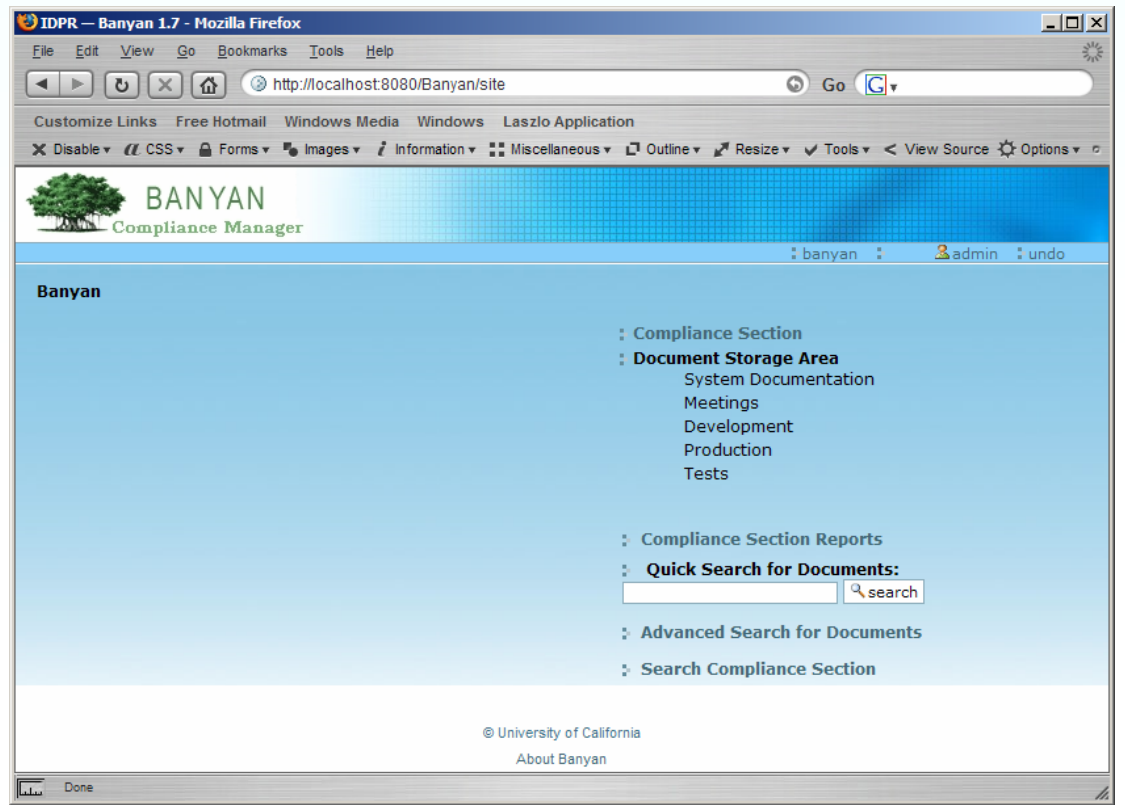




\subsection{User Name and Password}

Enter your user name and password. As with the URL above, you may have to contact your system administrator for a user name and password if you are running off of a server. If you are using Banyan on your workstation as installed by the setup.exe file, then you have a choice of login names:

\begin{tabular}{|l|l|l|}
\hline User Name & Password & Roles \\
\hline admin & $\begin{array}{l}\text { Whatever password you } \\
\text { provided as a default in the } \\
\text { setup dialog }\end{array}$ & $\begin{array}{l}\text { Basic reader capability } \\
\text { within Banyan, ability to } \\
\text { create new Banyan sites } \\
\text { (beyond the scope of this } \\
\text { document) }\end{array}$ \\
\hline Banyan_Configurator & Banyan_Configurator & $\begin{array}{l}\text { Configurator role -- has the } \\
\text { ability to configure Banyan. }\end{array}$ \\
\hline Banyan_Contributor & Banyan_Contributor & $\begin{array}{l}\text { Contributor role and has the } \\
\text { ability to add content to } \\
\text { Banyan. }\end{array}$ \\
\hline Banyan_Metadata_Editor & Banyan_Metadata_Editor & $\begin{array}{l}\text { Metadata_Editor role and } \\
\text { has the ability to edit } \\
\text { metadata in the Banyan } \\
\text { Document Storage Area. }\end{array}$ \\
\hline Banyan_Reader & Banyan_Reader & $\begin{array}{l}\text { Reader role and has the } \\
\text { ability to view Banyan } \\
\text { information. }\end{array}$ \\
\hline
\end{tabular}

Note: in most environments it is a really bad idea to keep the above passwords - even on your own workstation. If you are doing anything more than just checking out Banyan, then you will want to change the above defaults. Consult the Banyan System Administration Guide or a system administrator for help in changing users and passwords. 


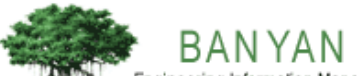

sich Engineering Information Manager

Log in with a user name and a password.

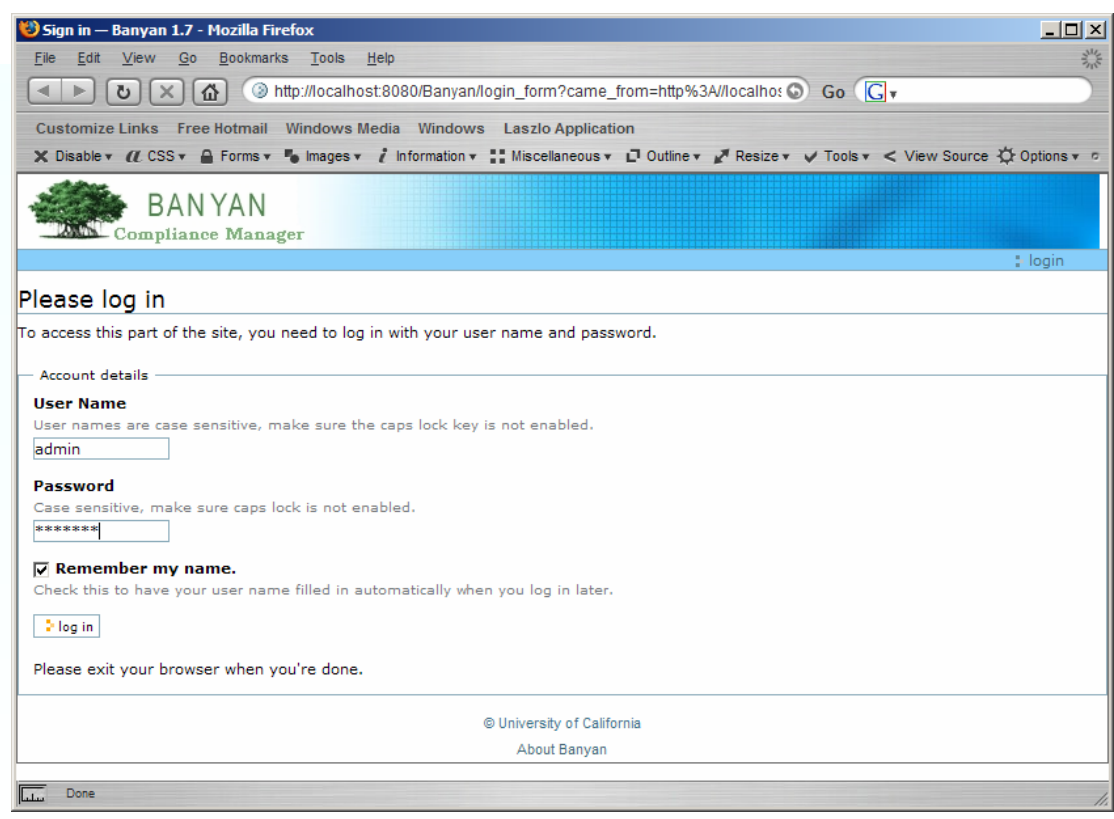




\section{Document Storage Area}

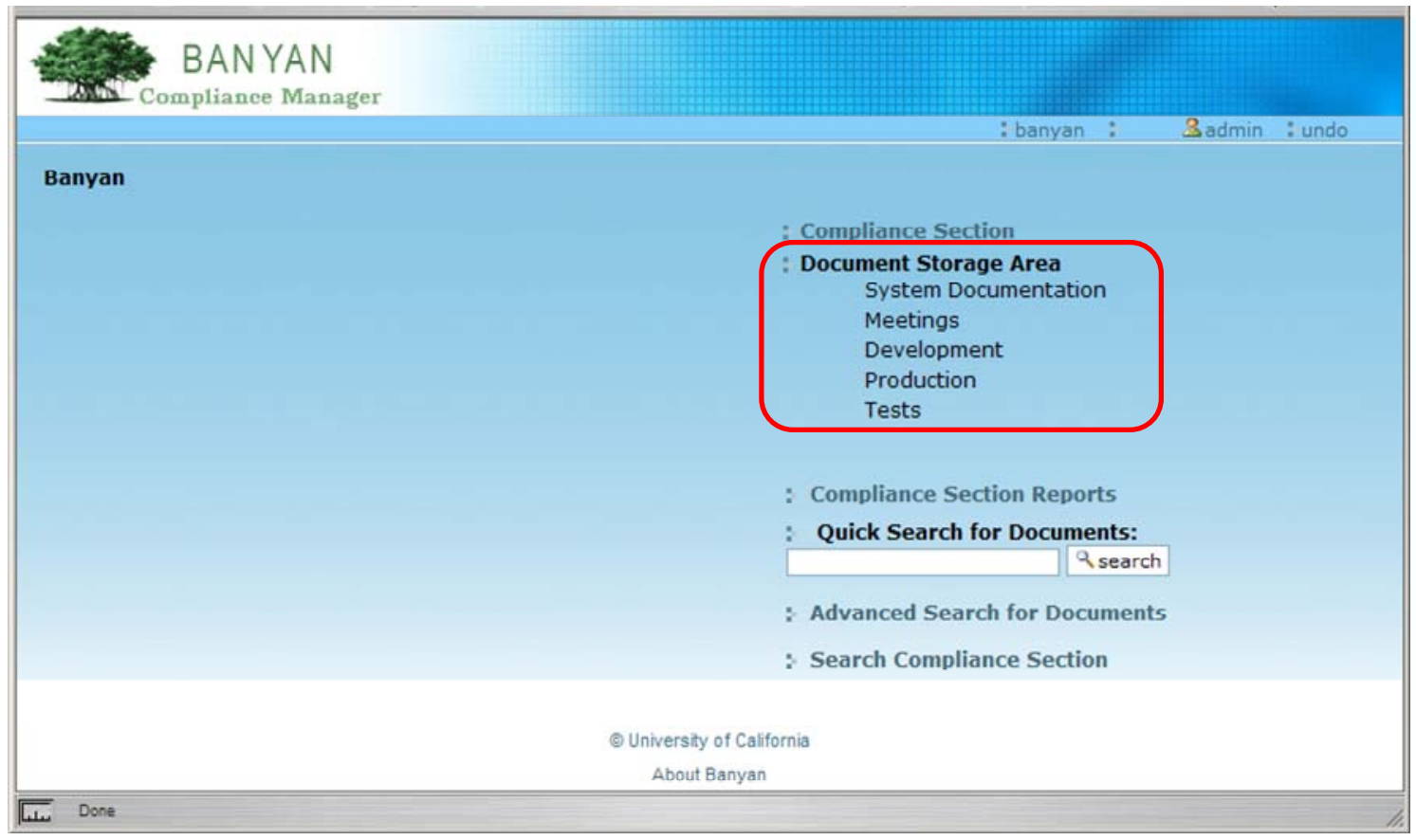

\subsection{System Documentation}

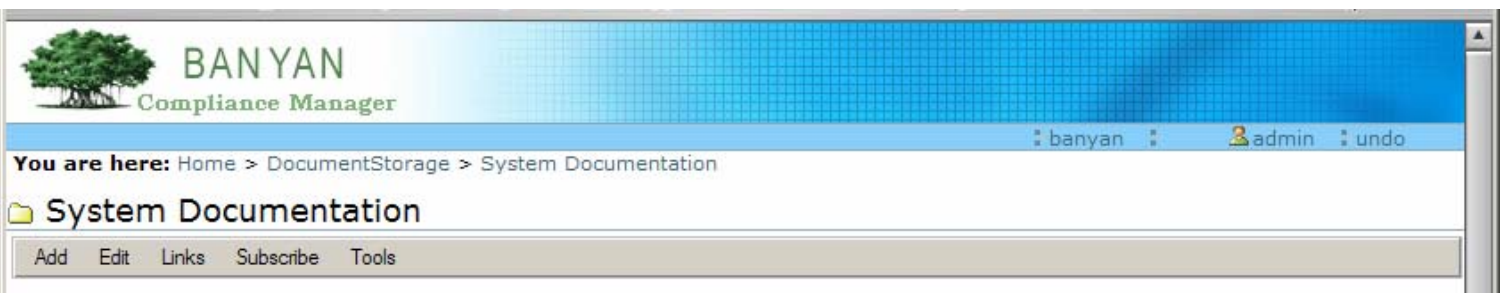

\subsection{Add}

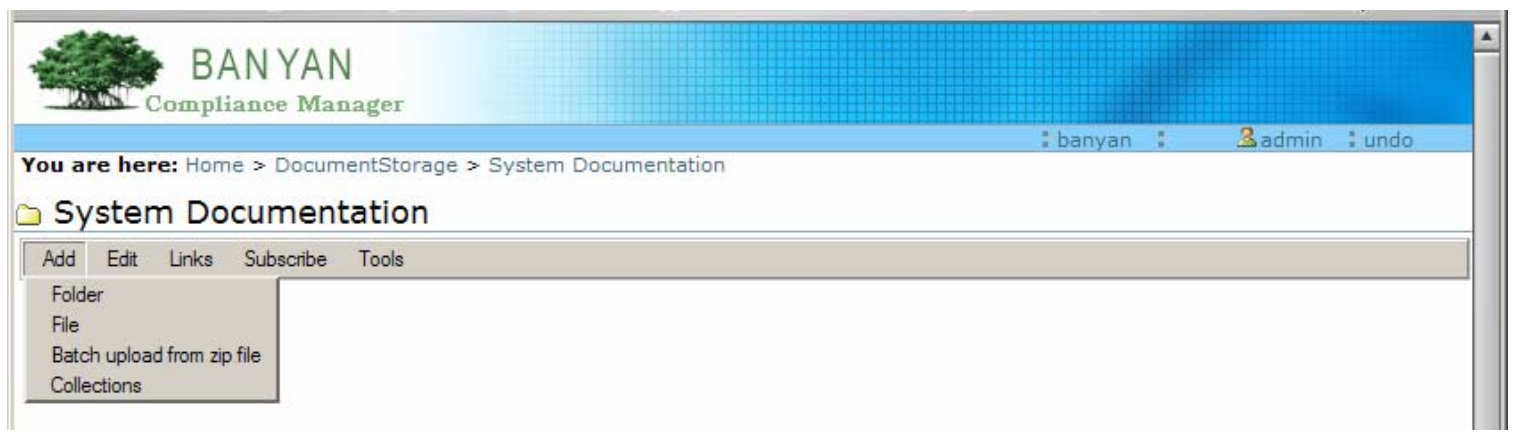


Engineering Information Manager

\subsubsection{Add Folder}

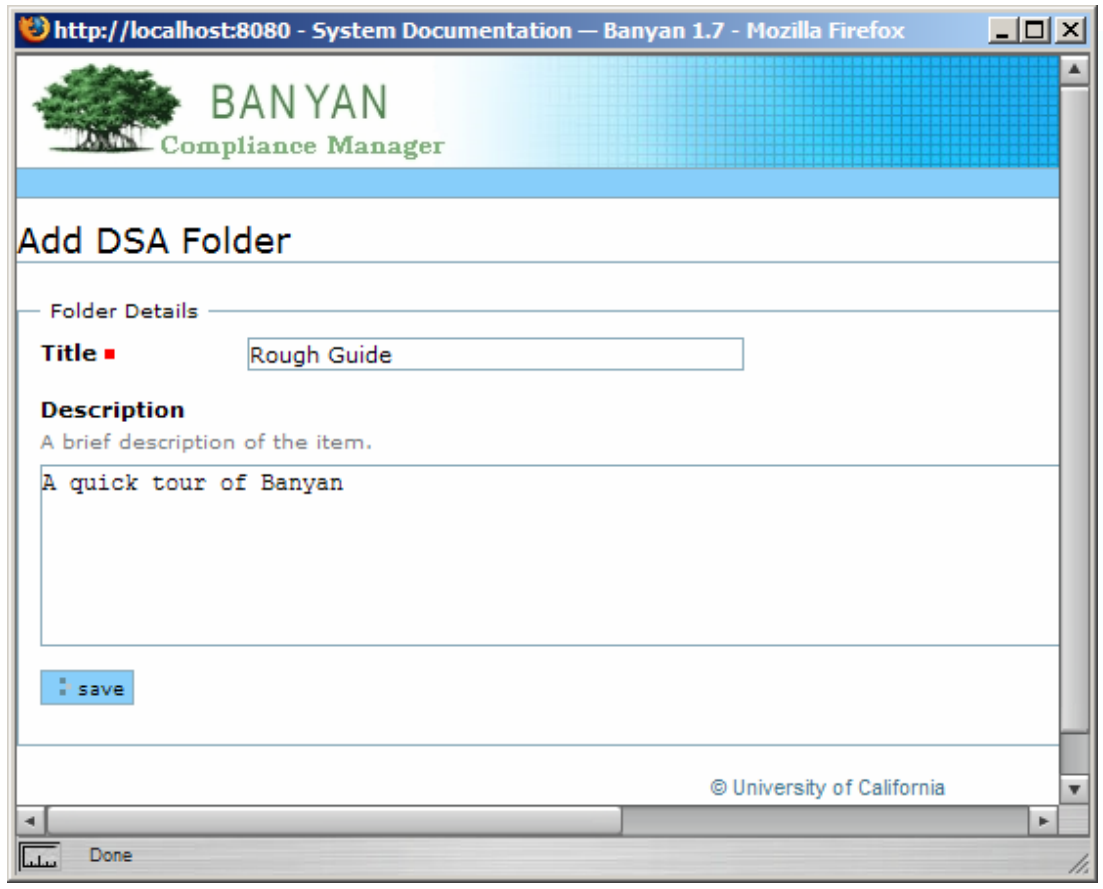

Produces:

\section{BANYAN}

ank Compliance Manager

You are here: Home > DocumentStorage > System Documentation

$\square$ System Documentation

\begin{tabular}{|ll}
\hline Add Edit Links Subscribe & Tools \\
\hline Rough Guide & A quick tour of Banyan
\end{tabular}




\subsubsection{Add File}

\section{Select Folder}

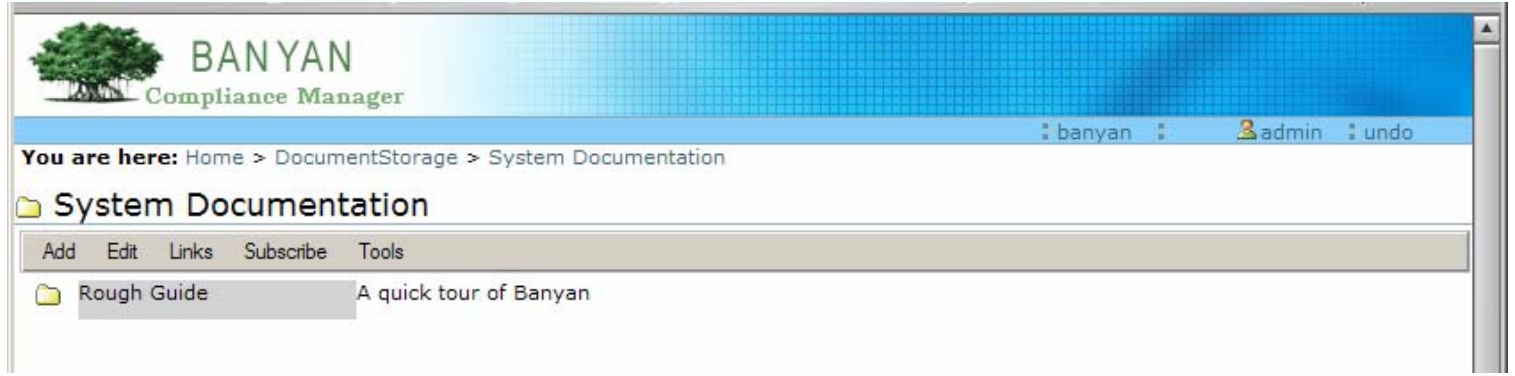

Add File

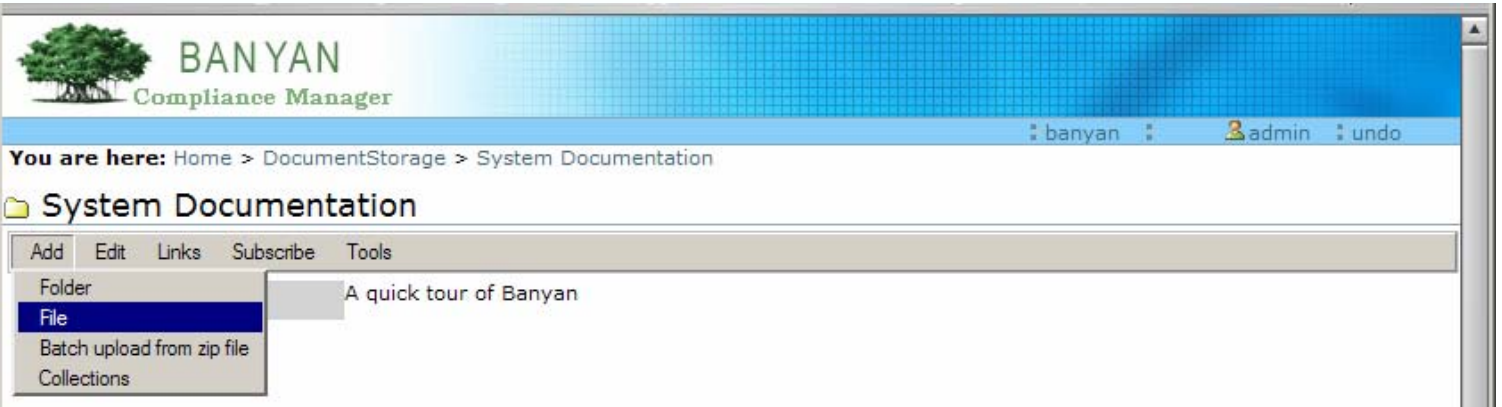

Add File dialog - Upload File $\boldsymbol{m}$ is the only required field

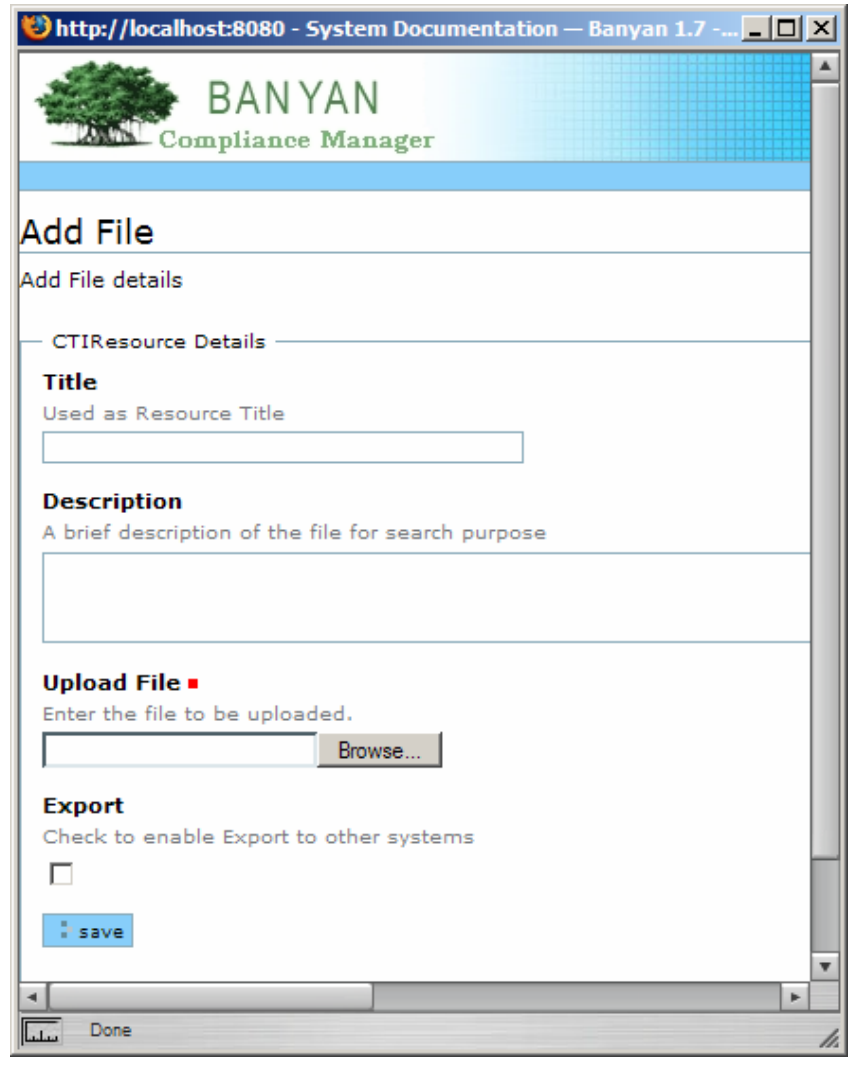




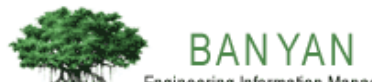

Add metadata

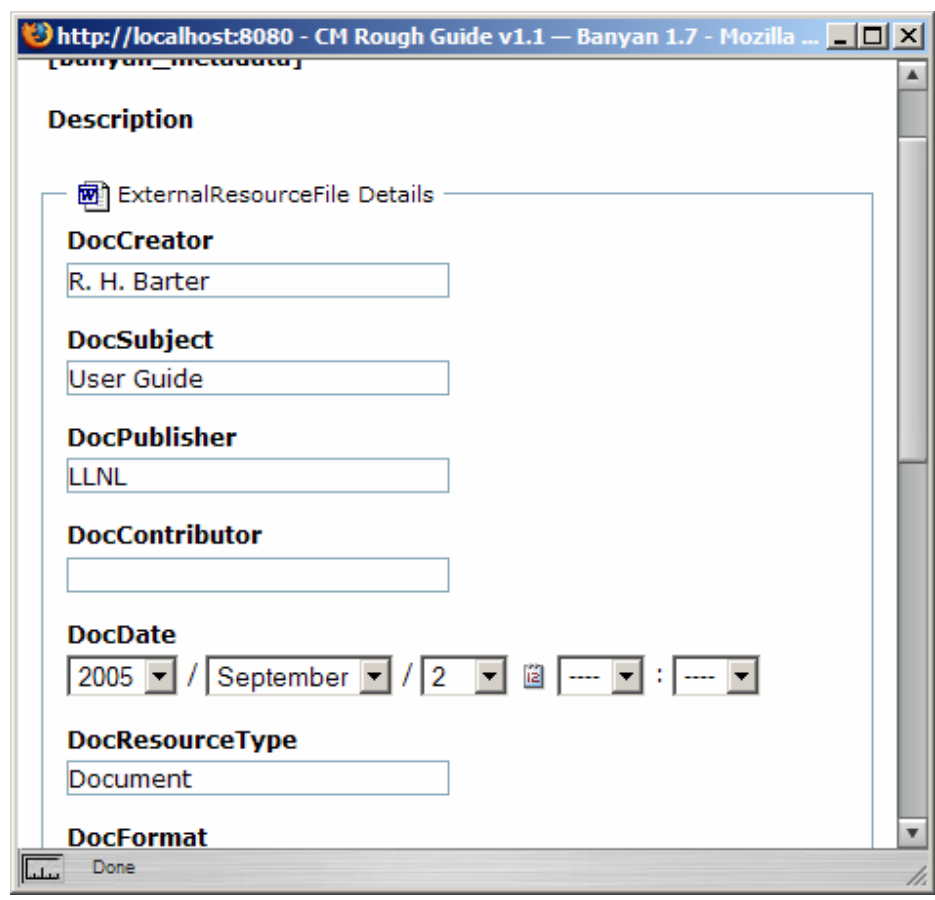

\section{Click Save}

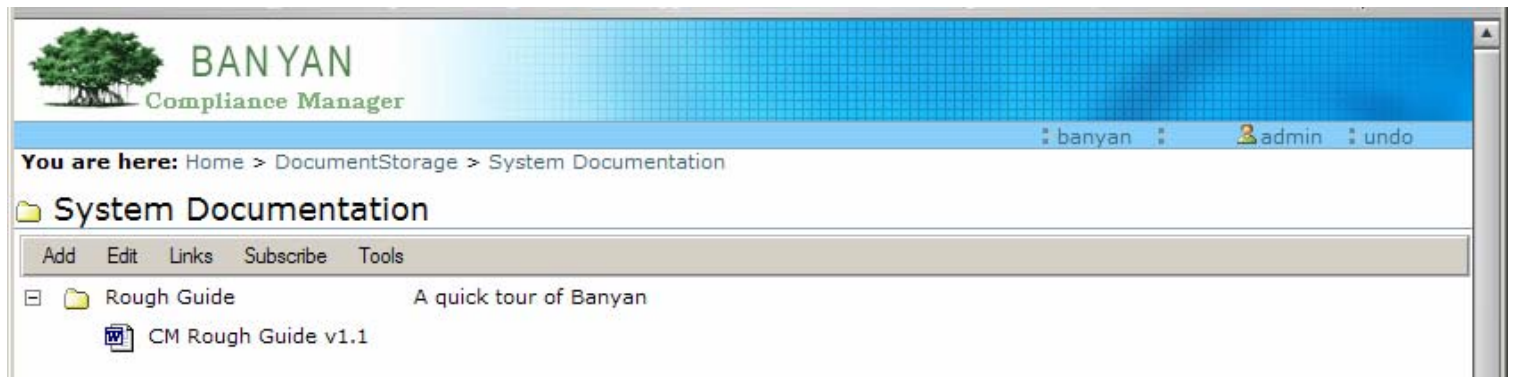




\subsubsection{Add a zip file}

\section{BANYAN}

sik Compliance Manager

You are here: Home > DocumentStorage > System Documentation

\section{$\checkmark$ System Documentation}

\begin{tabular}{l}
\hline Add Edit Links Subscribe Tools \\
Folder \\
File \\
Batch upload from zip file \\
\hline Collections \\
\hline
\end{tabular}

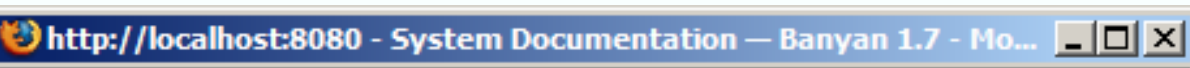

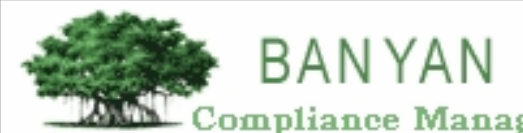

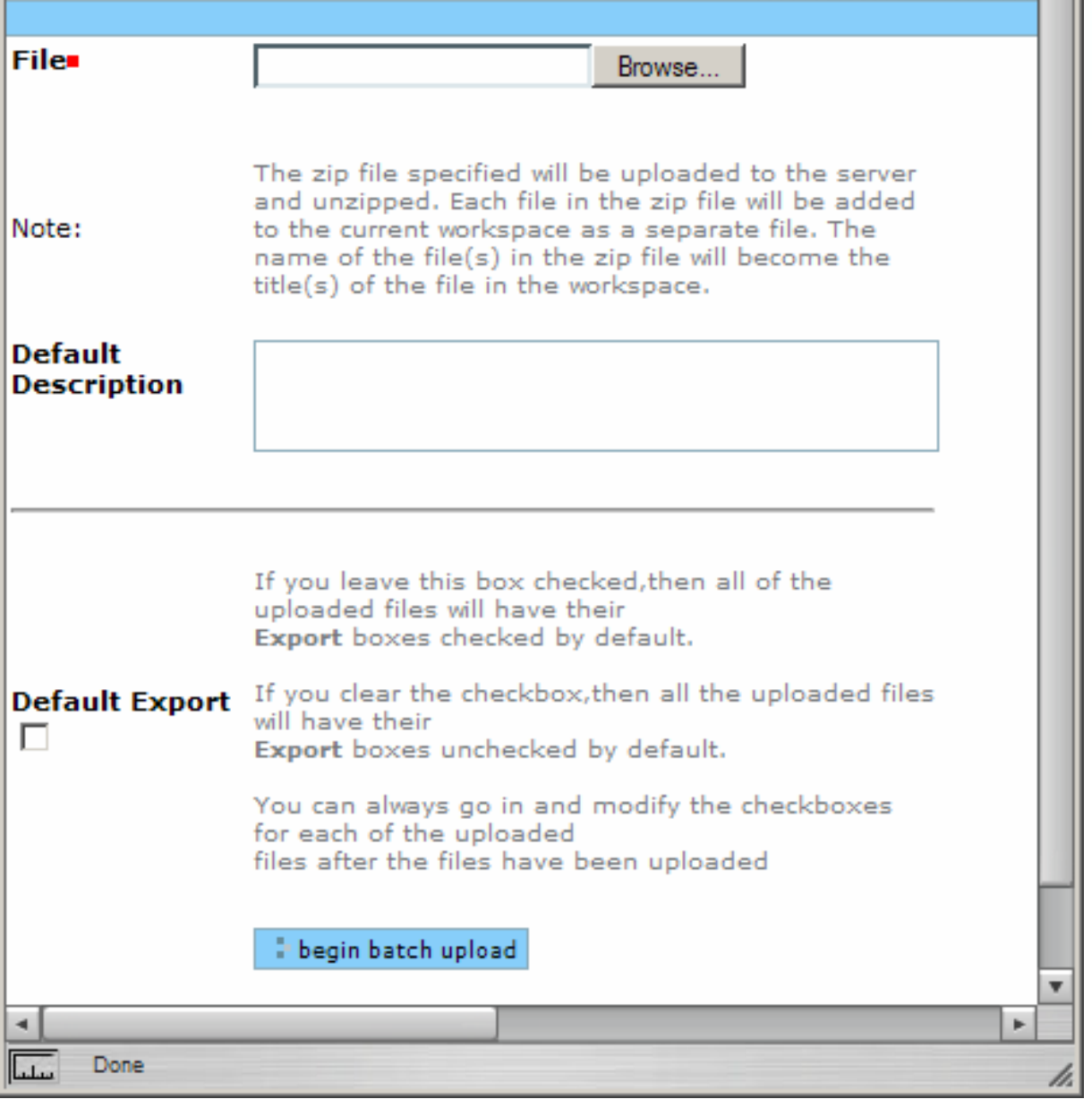




\subsubsection{Add a Collection}

\section{BANYAN}

sin Compliance Manager

You are here: Home > DocumentStorage > System Documentation

\section{$\bullet$ System Documentation}
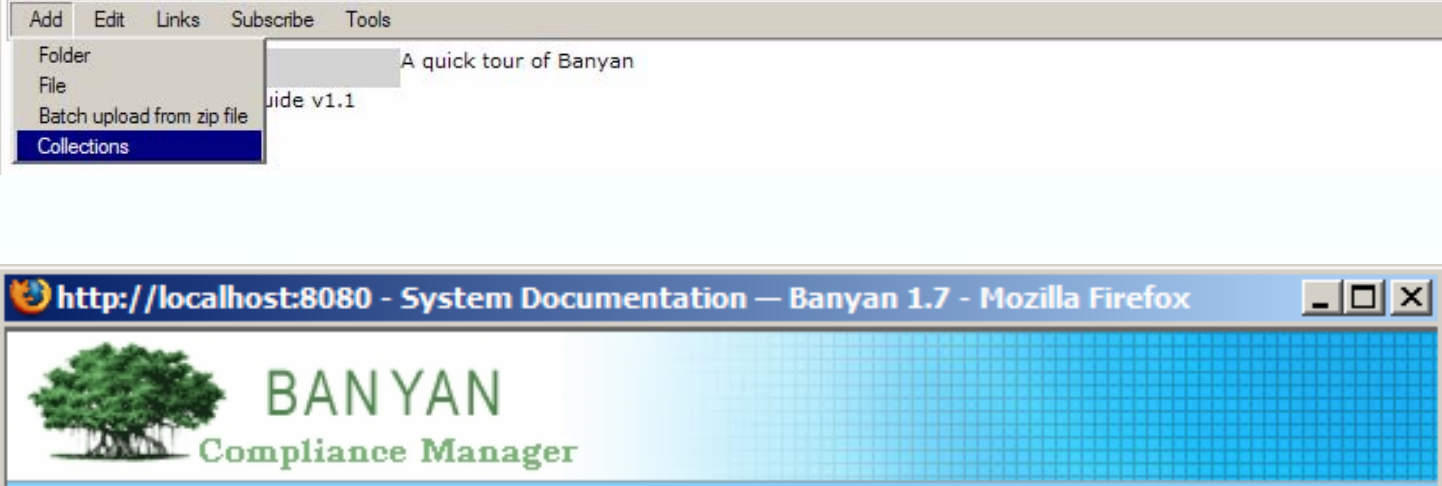

Title=

File $=$

Browse...

The zip file specified will be uploaded to the server

and unzipped. Each file in the zip file will be added

to the current workspace as a separate file. The name of the file(s) in the zip file will become the title(s) of the file in the workspace.

Export

Г

upload collections

(9) University of California

About Banyan

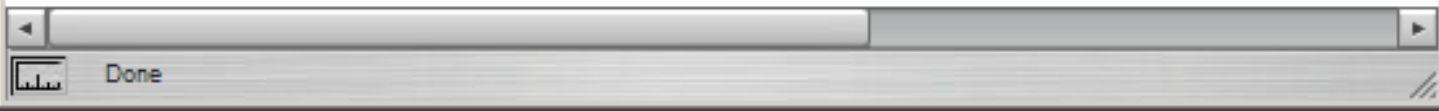




\subsection{Edit}

\subsubsection{Title and Description}
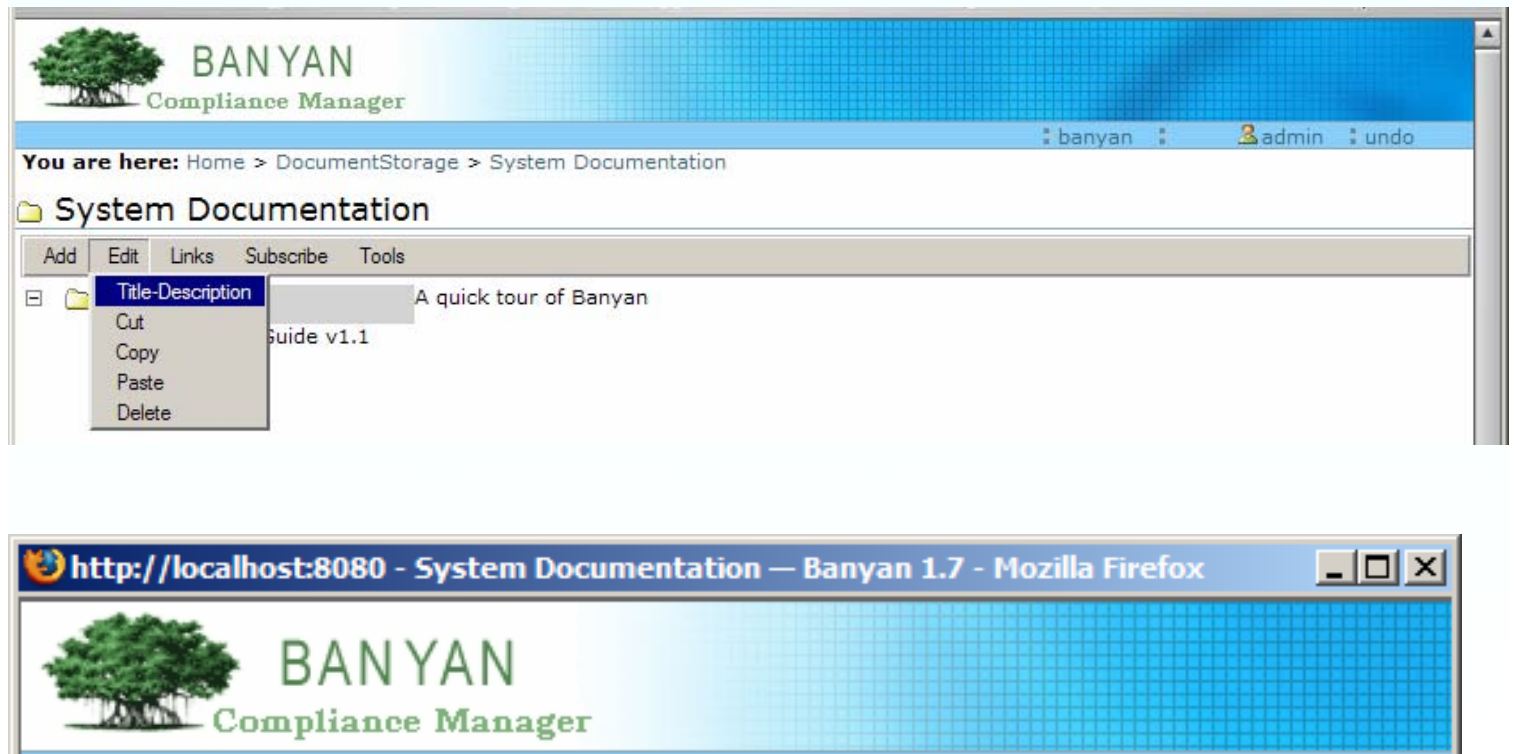

\section{Edit DSA Folder}

Folder Details

Title =

Rough Guide

\section{Description}

A brief description of the item.

A quick tour of Banyan 


\subsubsection{Edit Metadata}

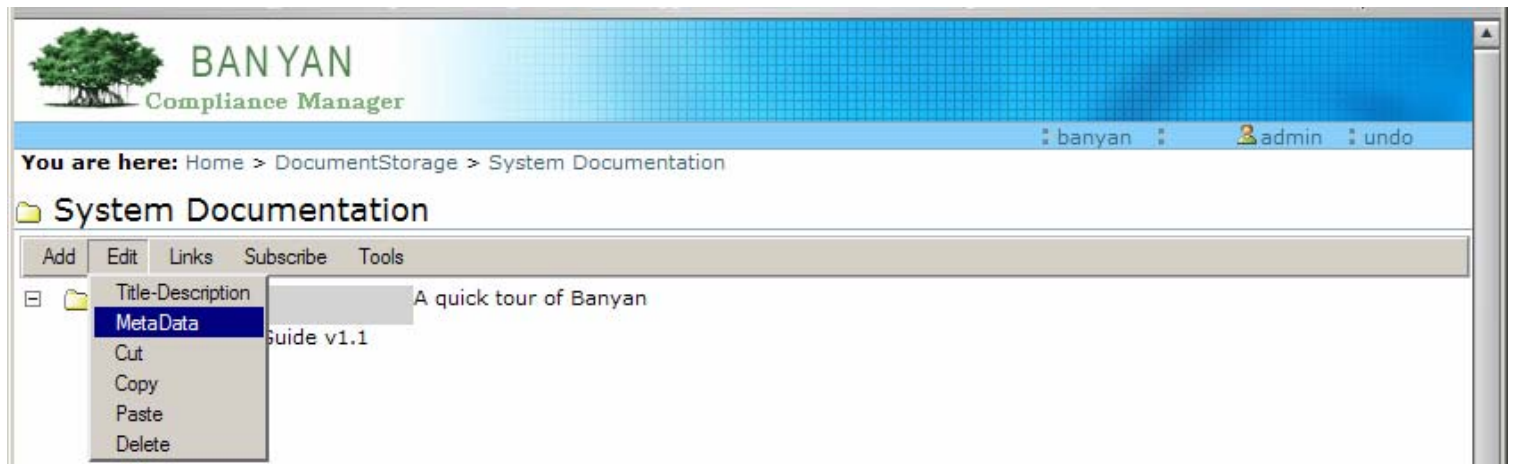

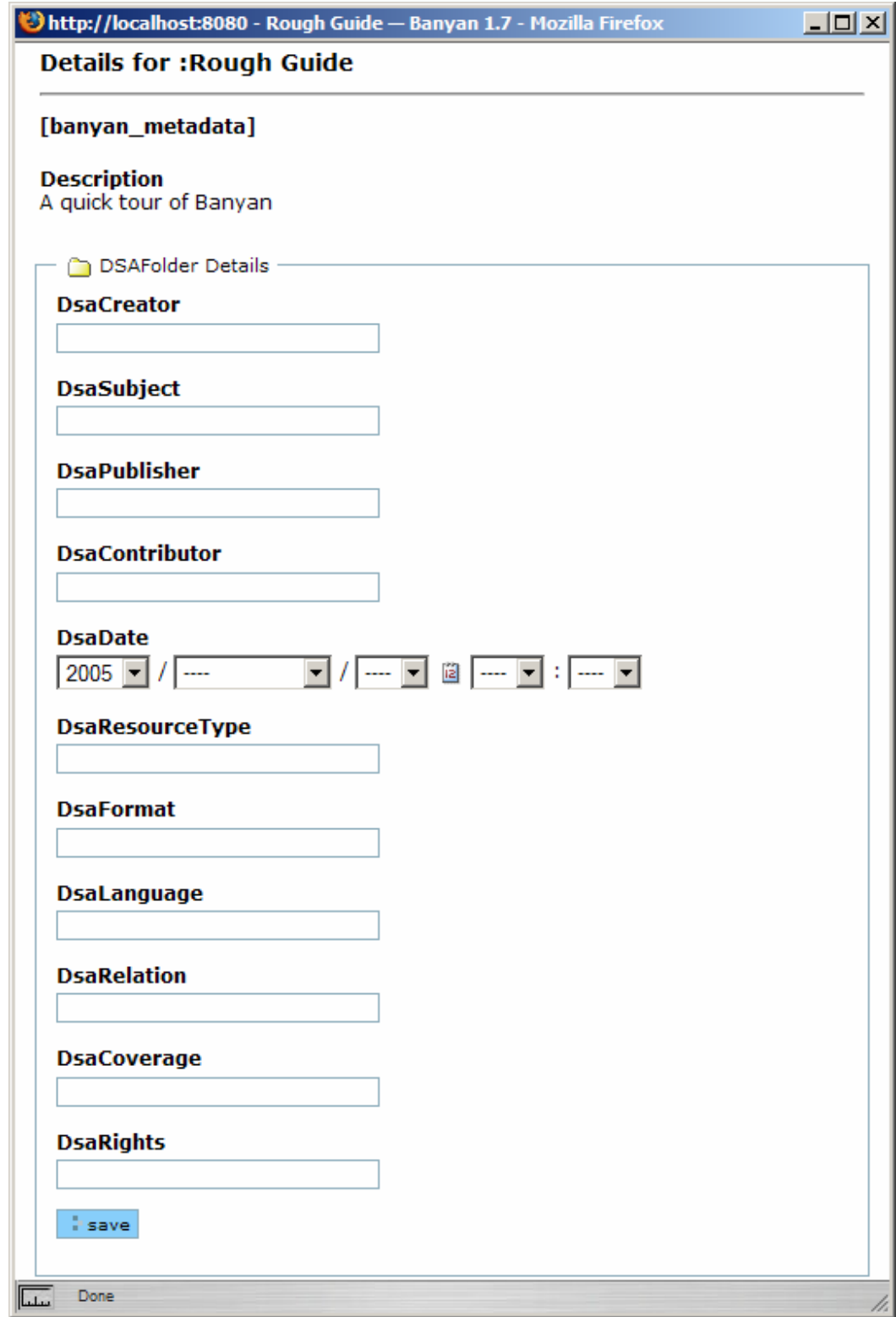




\subsubsection{Cut/Copy/Paste/Delete}

\begin{tabular}{|l||}
\hline BAN YAN \\
\hline You are here: Home > DocumentStorage > System Documentation \\
System Documentation \\
\begin{tabular}{|l|l||}
\hline Edit Links Tools \\
Title-Description & ide \\
MetaData & A quick tour of Banyan \\
Cut & \\
Copy & \\
Paste \\
Delete
\end{tabular} \\
\hline
\end{tabular}

\subsubsection{Undo}

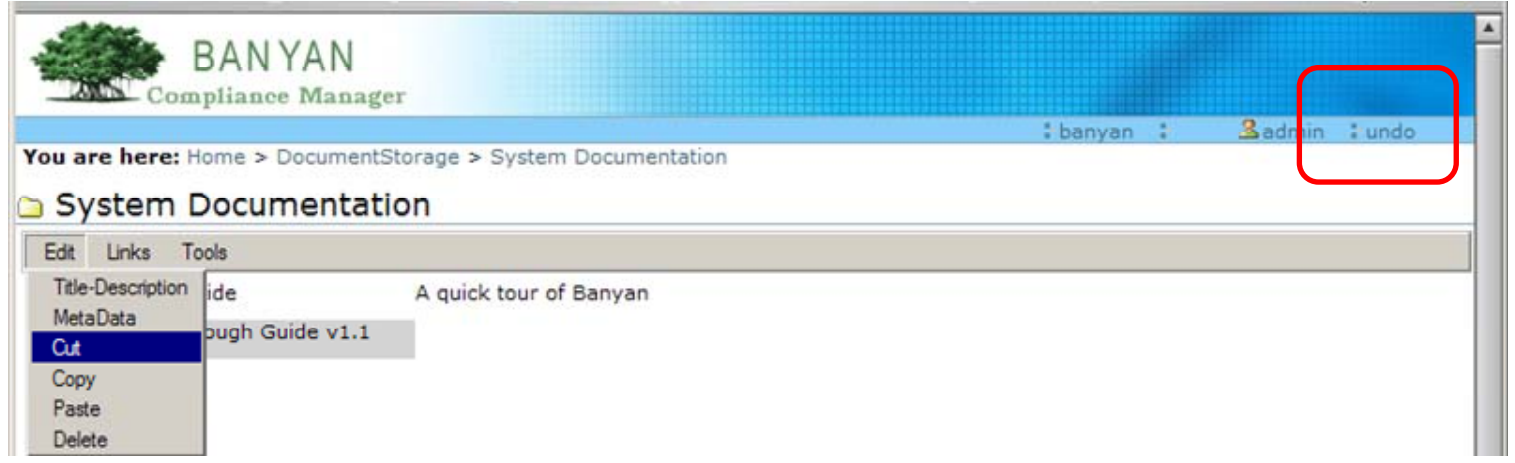

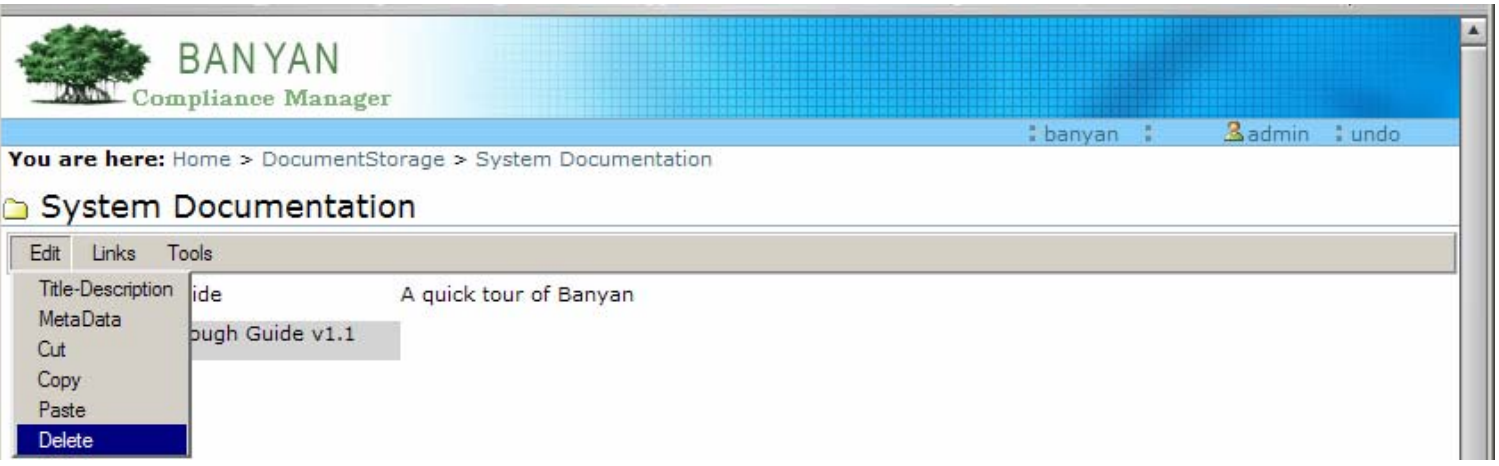

\section{weras BANYAN}

Sis Compliance Manager

You are here: Home > DocumentStorage > System Documentation

\section{$\square$ System Documentation}

\begin{tabular}{ll}
\hline Add Edit Links Subscribe & Tools \\
$\square$ Rough Guide & A quick tour of Banyan
\end{tabular}


BAN YAN

Engineering Information Manage

\section{BANYAN}

Sis Compliance Manager

\section{Undo actions}

This applications transactional feature allows you to easily undo changes made to the applications settings or data. You can revert the applicat

Select one or more transactions below and then click on the "Undo" button to undo the transactions. Note that even though a transaction is sho transaction.

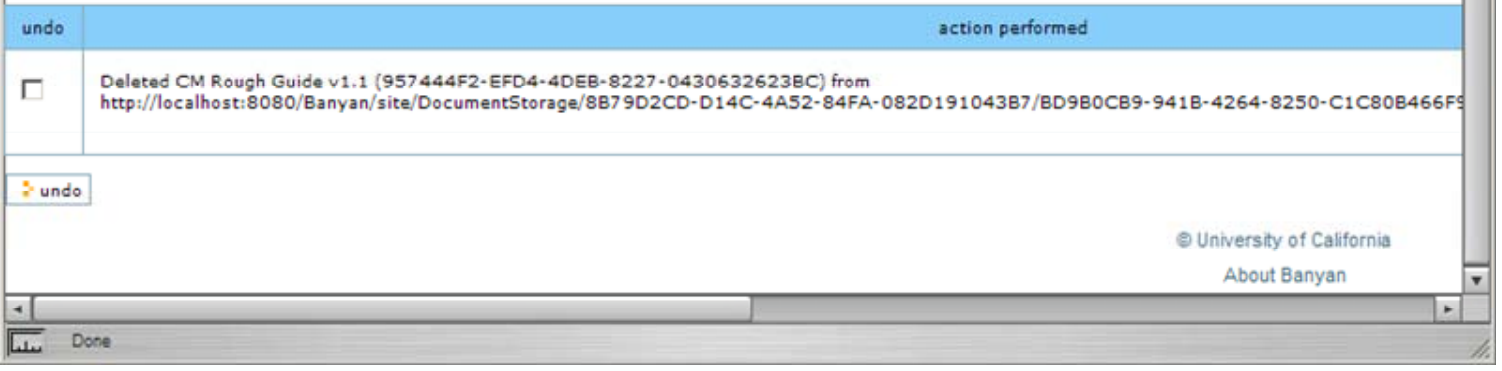

\section{BAN YAN}

Compliance Manager

You are here: Home > DocumentStorage > System Documentation

(1) Transaction(s) undone.

$\square$ System Documentation

Add Edit Links Subscribe Tools

$\boxminus \square$ Rough Guide A quick tour of Banyan

国 CM Rough Guide v1.1 


\subsection{Links}

\subsubsection{Create a link}

Copy the link target (destination)

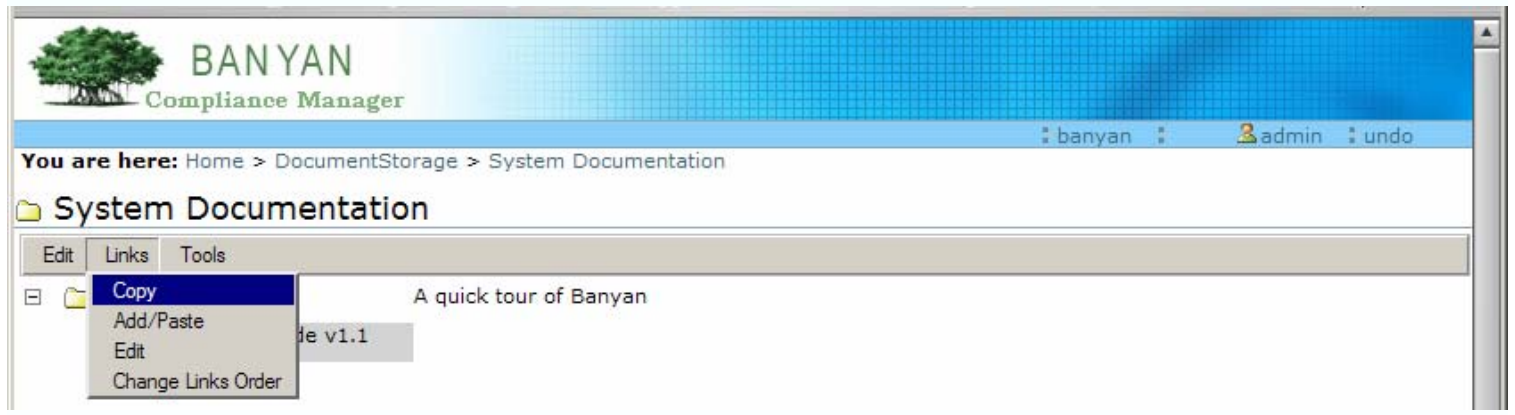

Go to another location and Add/Paste the link

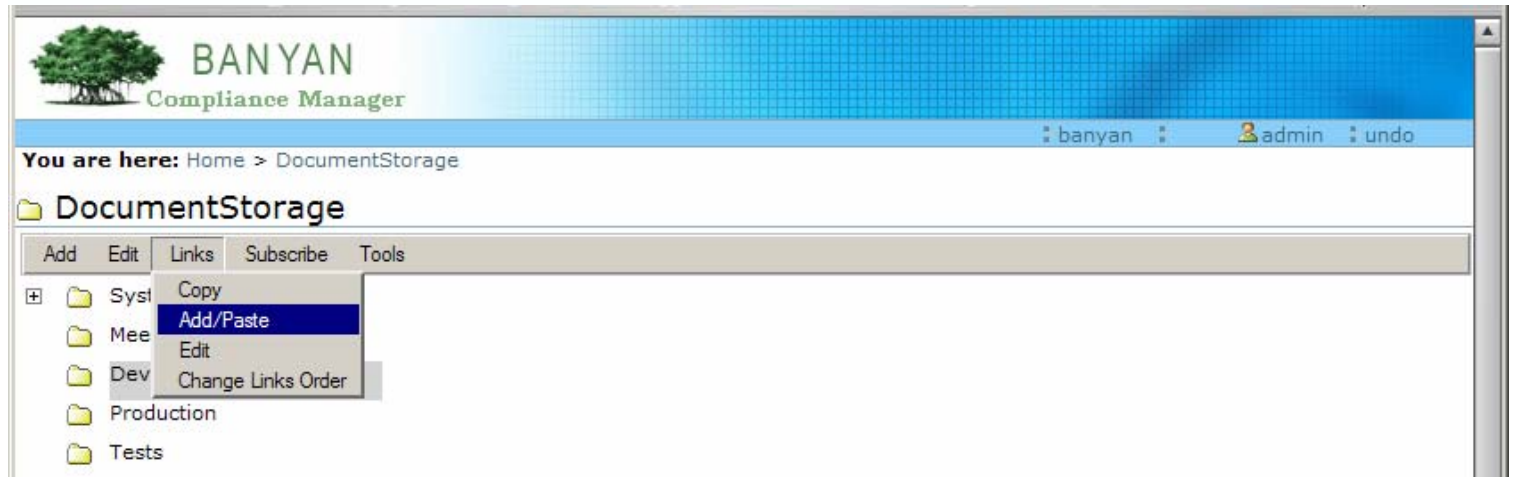

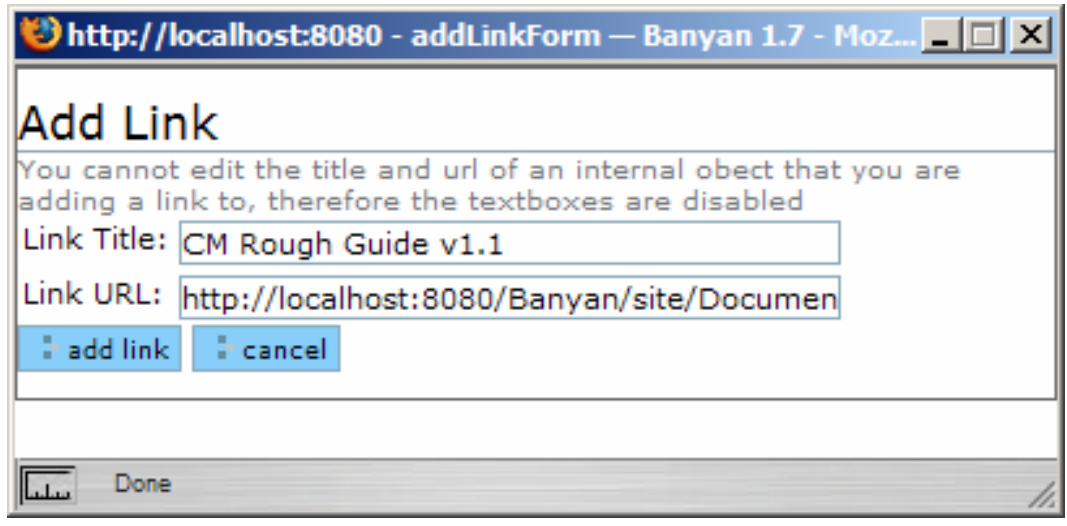


Link symbol appears

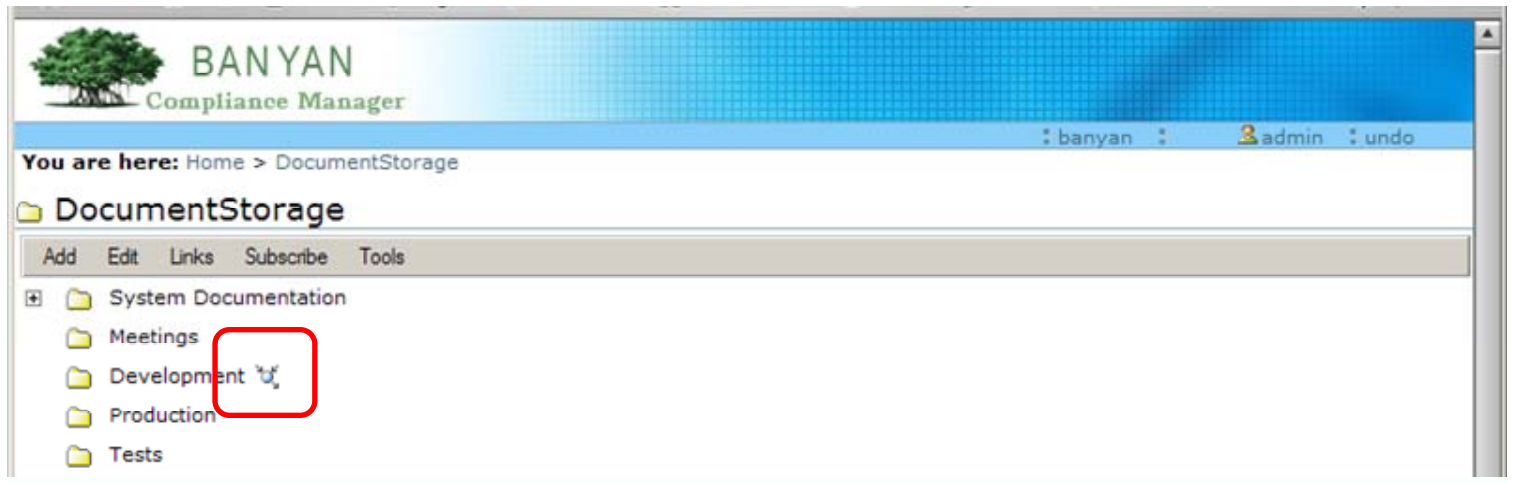

Link window shows link to target

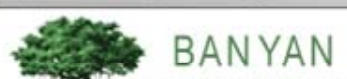

Sis Compliance Manager

You are here: Home > DocumentStorage

\section{$\checkmark$ DocumentStorage}

Add Edit Links Subscribe Tools

(t) $\square$ System Documentation

$\square$ Meetings

(1) Development "ै

$\square$ Production

$\square$ Tes Link To:CM Rough Guide v1.1 


\subsubsection{Edit Links}

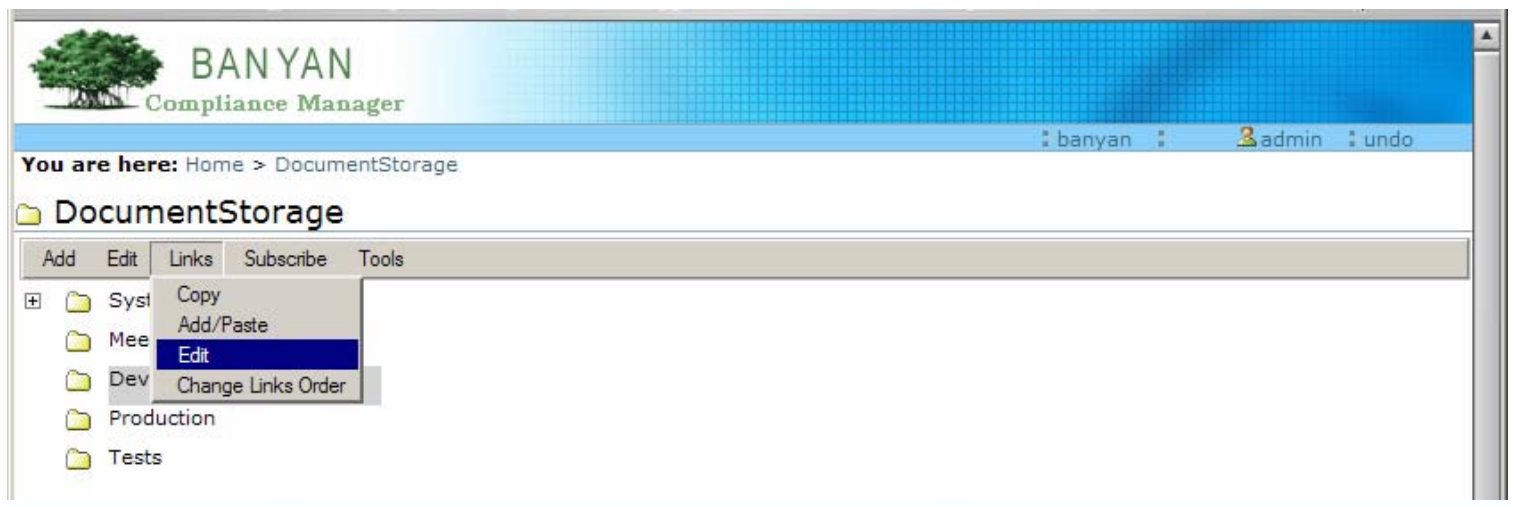

Cut/Copy/Paste links

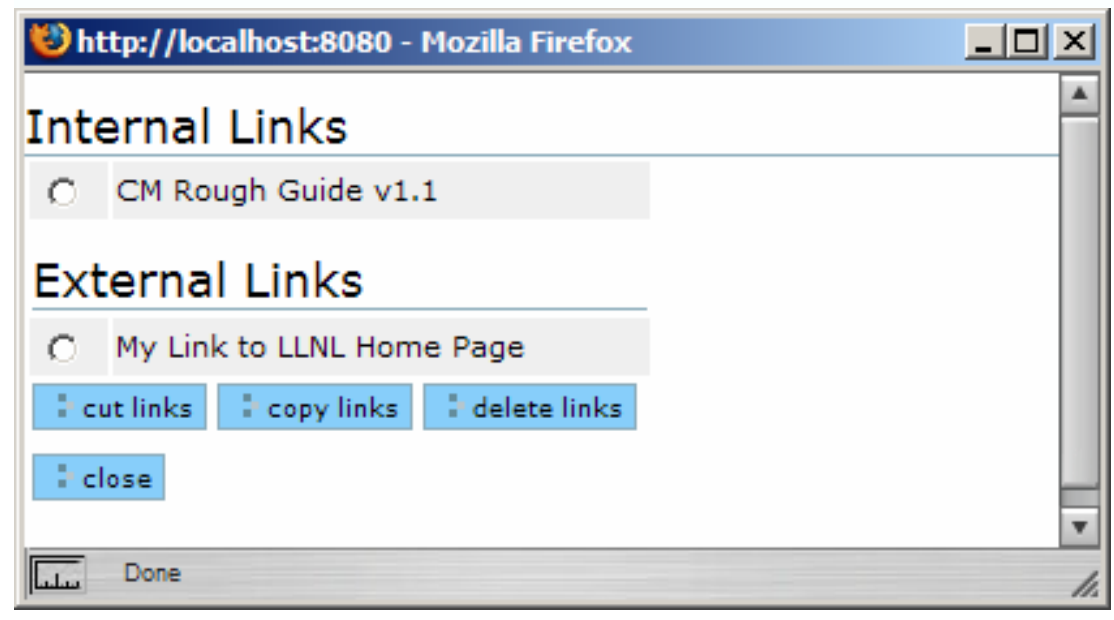




\subsection{Subscribe to Changes}

\subsubsection{Add a Subscription}

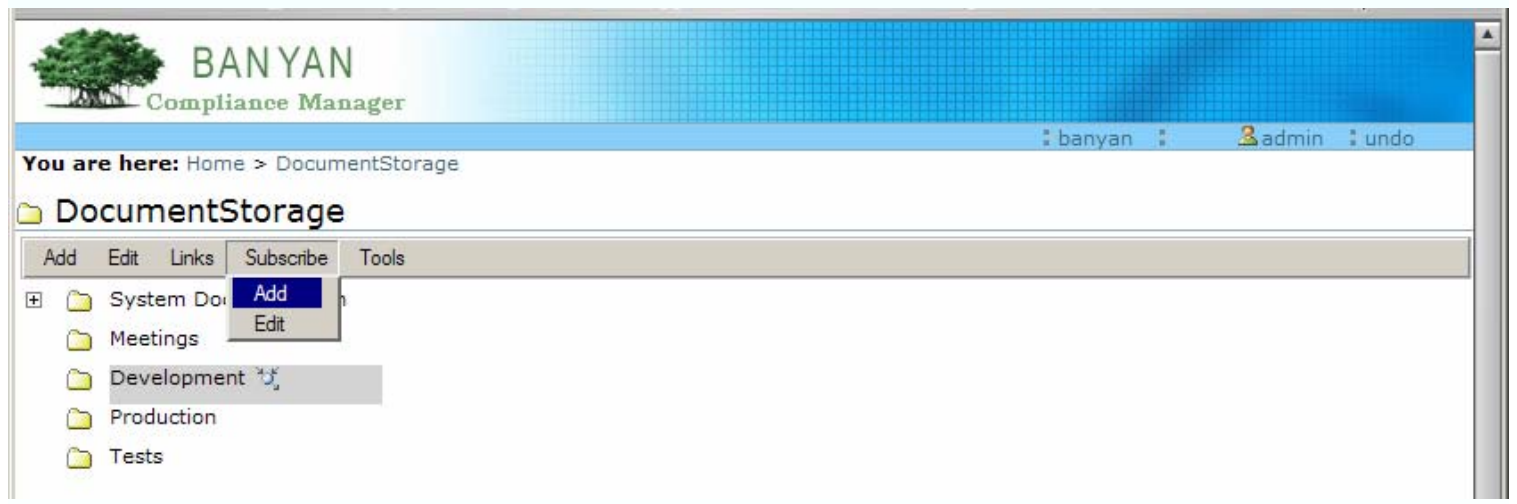

Icon added

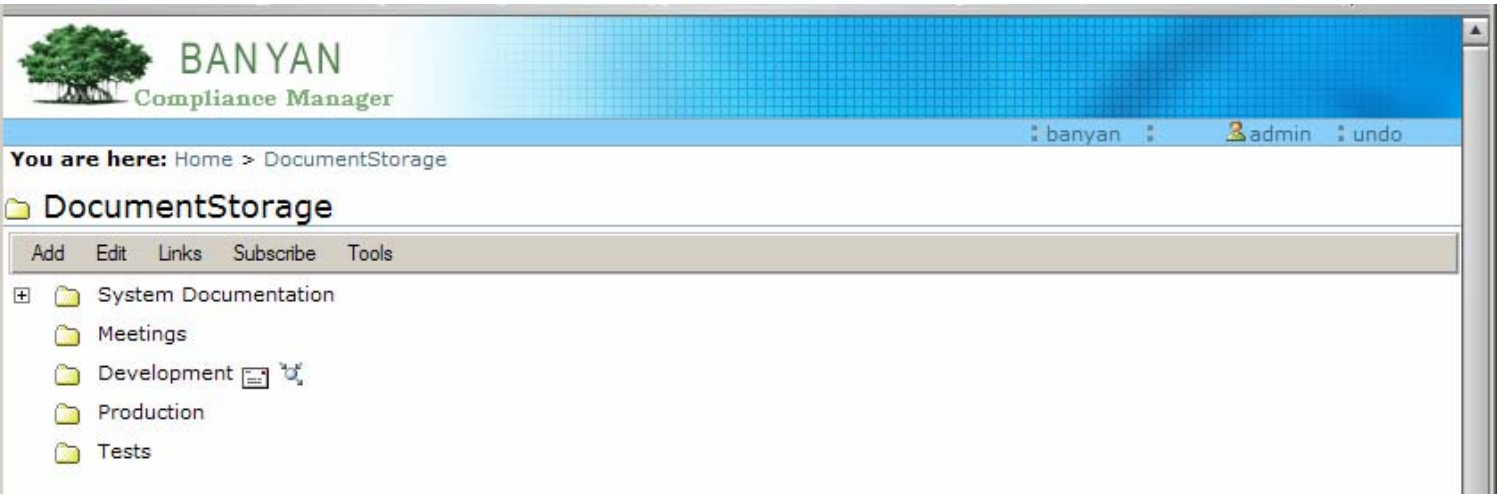




\subsubsection{Edit Subscriptions}

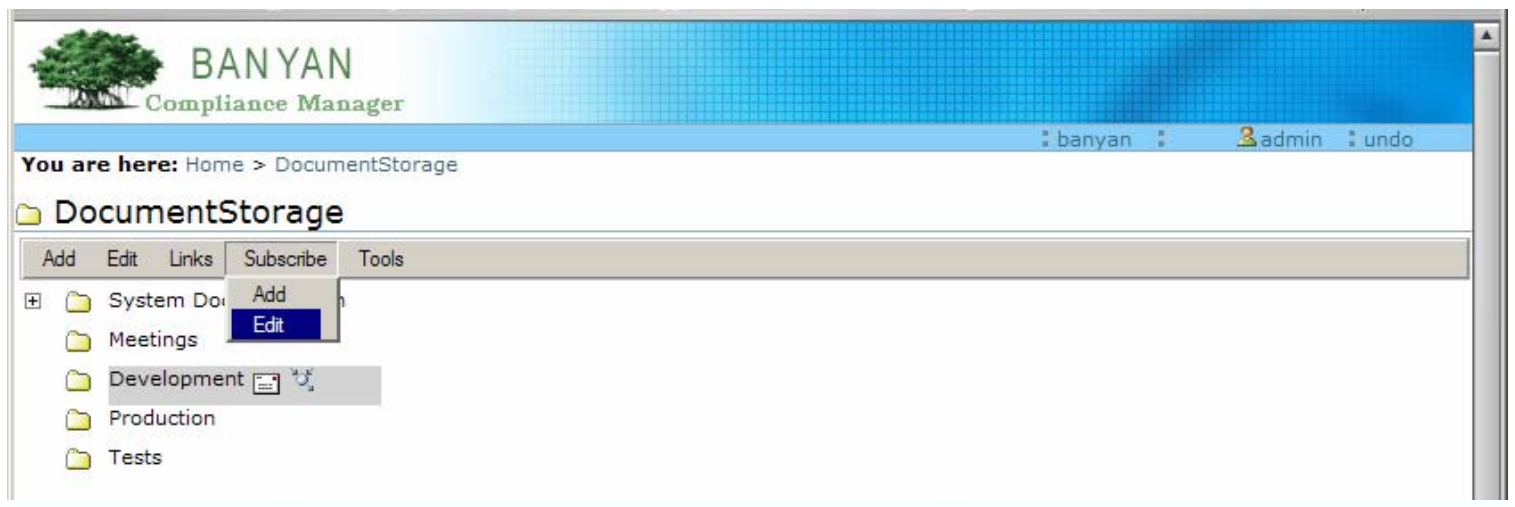

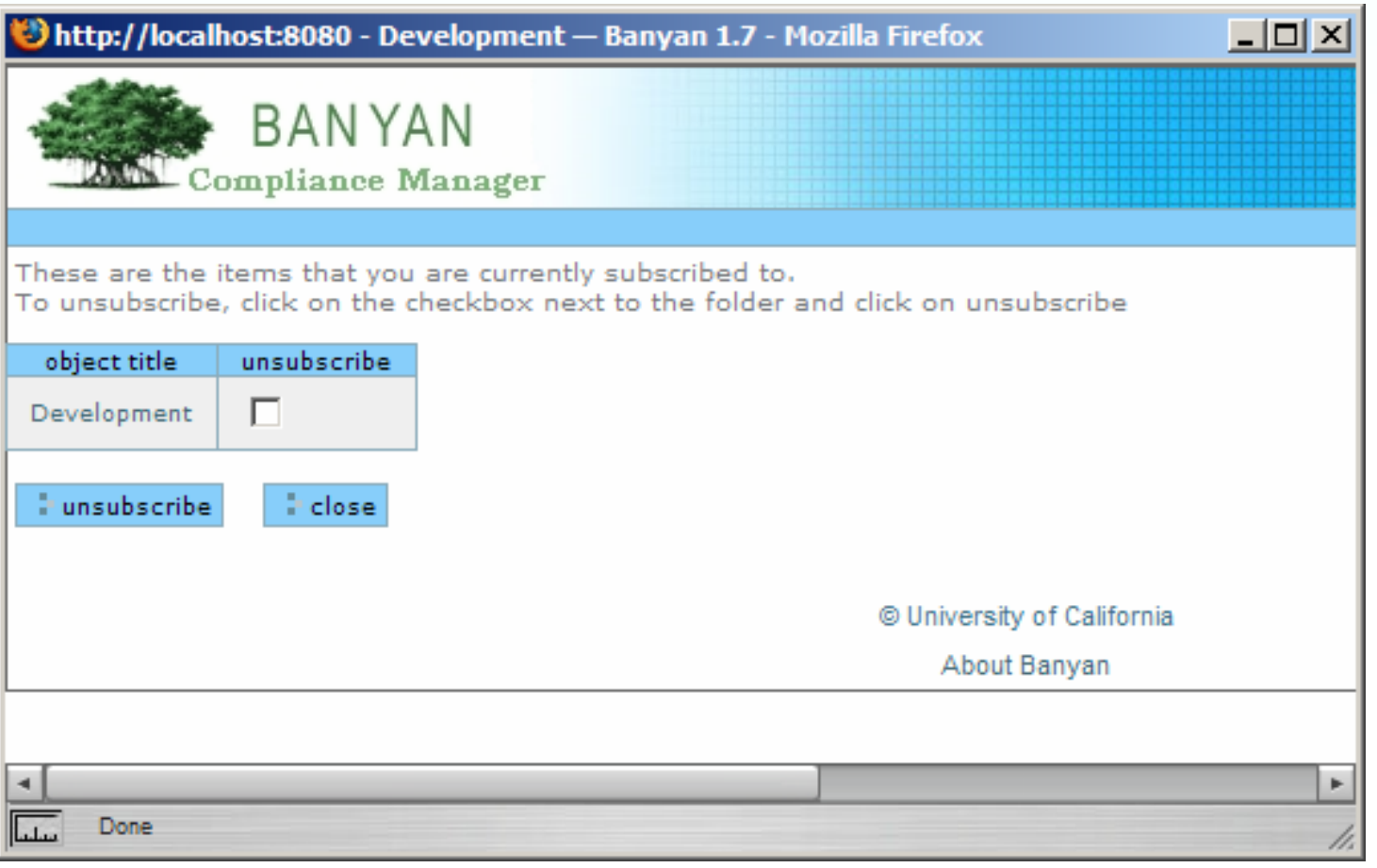




\subsection{Tools}

\subsubsection{Change Display Order}

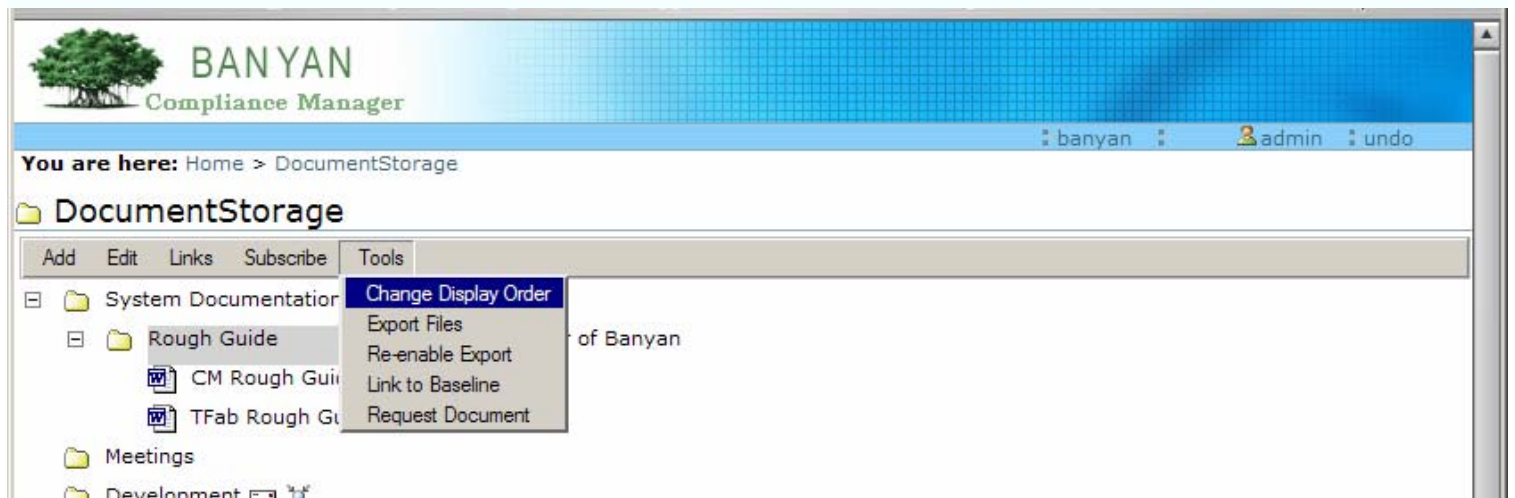

32 http://localhost:8080 - Rough Guide - Banyan 1.7 - Mozilla Firefox $-\mid$ 미 X

\section{Rough Guide}

A quick tour of Banyan

\begin{tabular}{|l|c|c|}
\hline Title & order \\
\hline 国 CM Rough Guide v1.1 & - \\
国 TFab Rough Guide v1.0 & - \\
\hline "up " down " top " bottom by 1
\end{tabular}

" i am satisfied

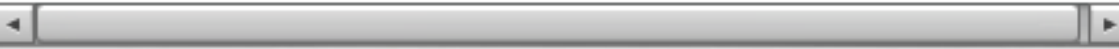

$\sqrt{\text { Luen }}$ Transferring data from localhost. 


\subsubsection{Export Files}

Only available if you have metadata editor role and files have been marked for export.

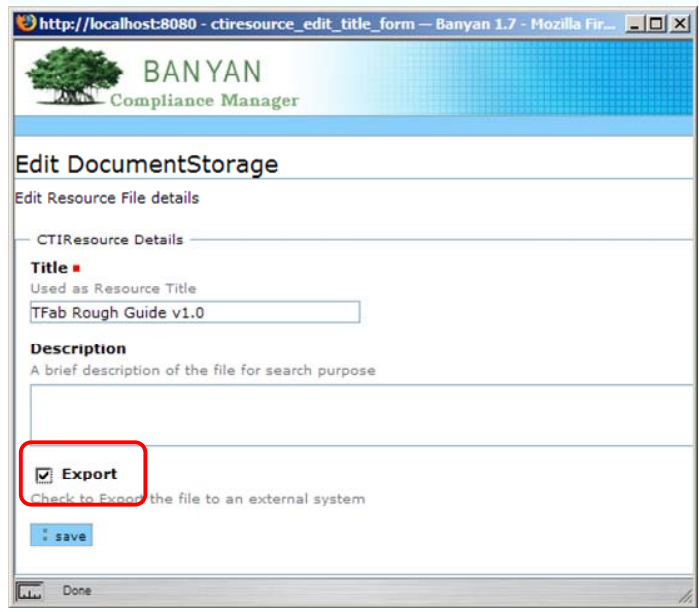

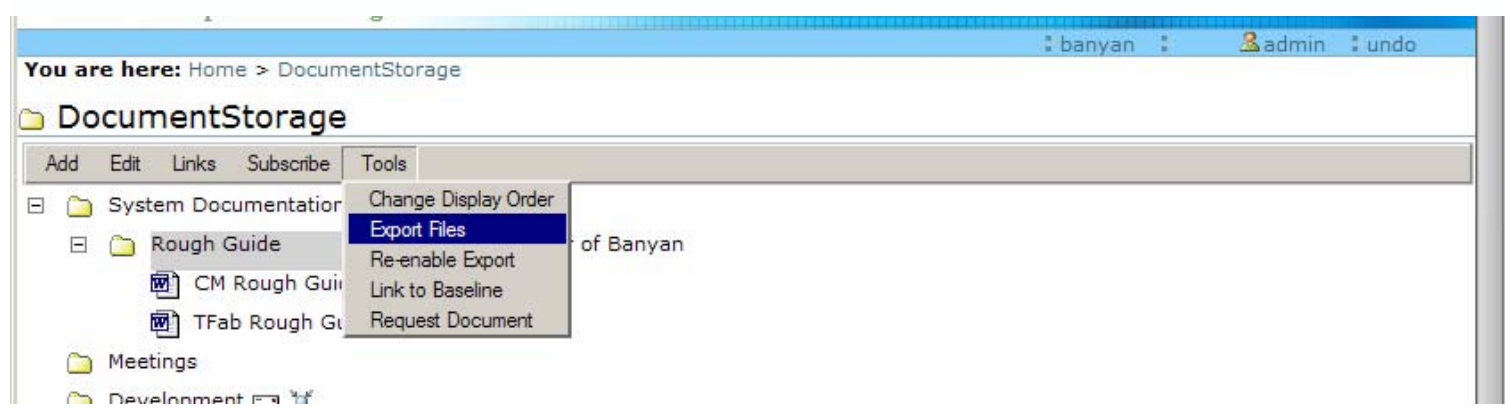

\section{3 http://localhost:8080 - Export Report - Mozilla Firefox}

\section{Export Message:}

1: DocumentStorage > System Documentation > Rough Guide > CM Rough Guide v1.1

2: DocumentStorage > System Documentation > Rough Guide > TFab Rough Guide v1.0 


\subsubsection{Re-enable Export}

Once a file has been exported its Export checkbox is disabled and it will not be exported again is Tools/Export Files is selected.

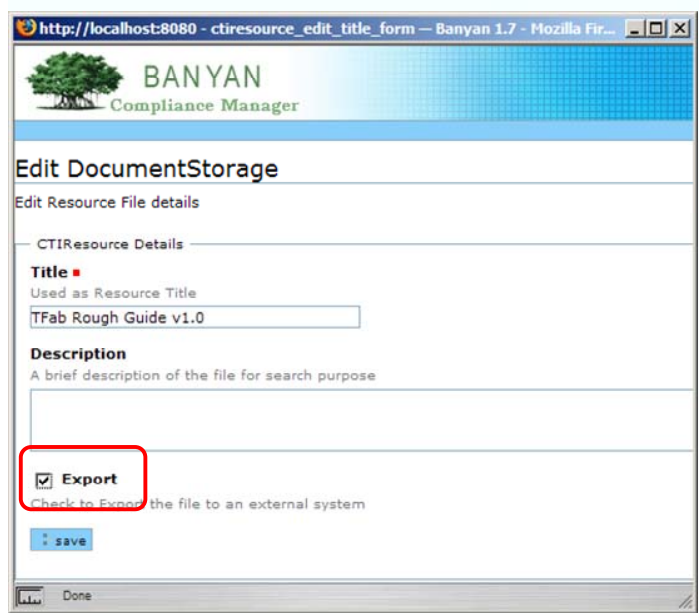

Re-enabling Export resets the file so that it can be exported again.

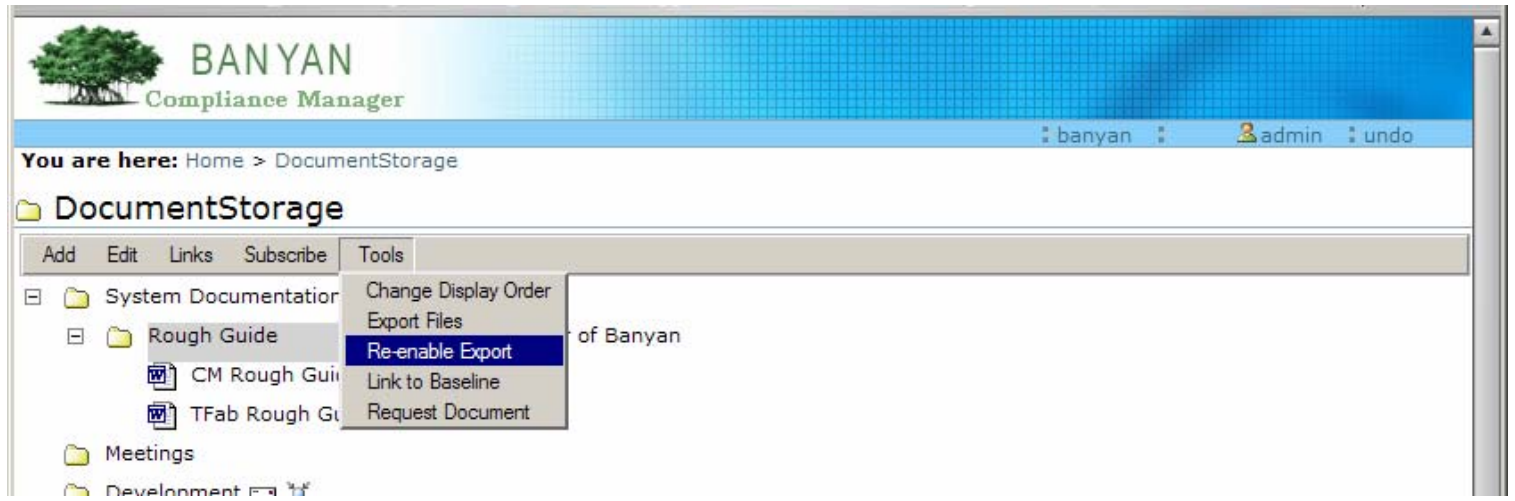




\subsubsection{Request Documents}

Interface to distributed workflow system.

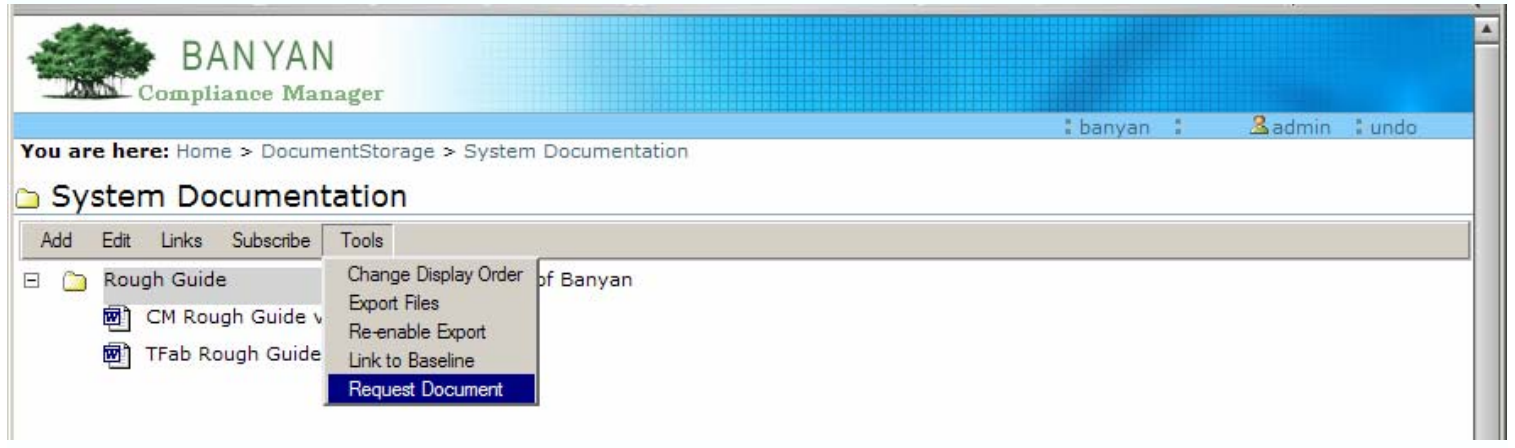

For now this feature is configured to open Google in a new window,

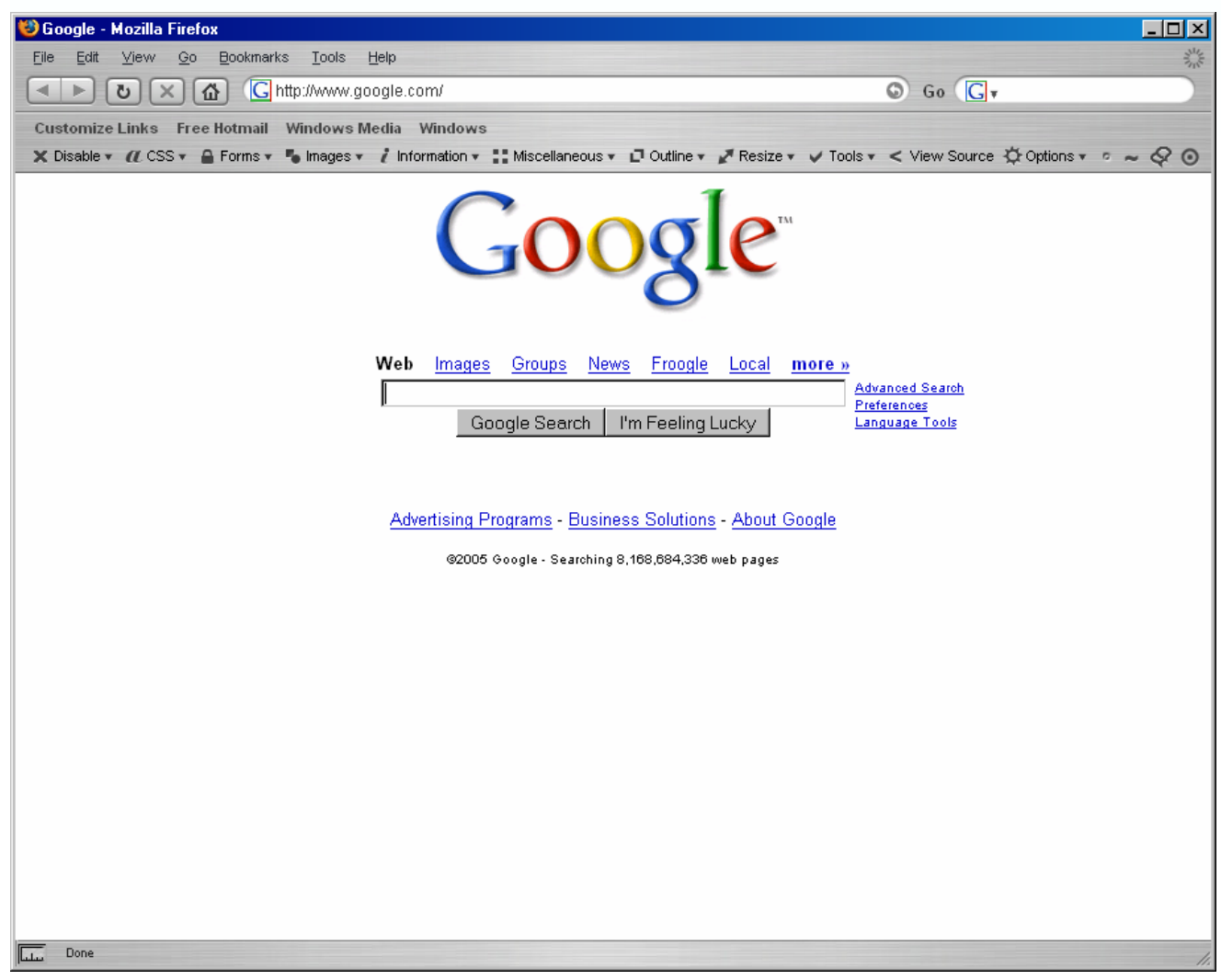




\section{Searching}

\subsection{Quick Search of Documents}

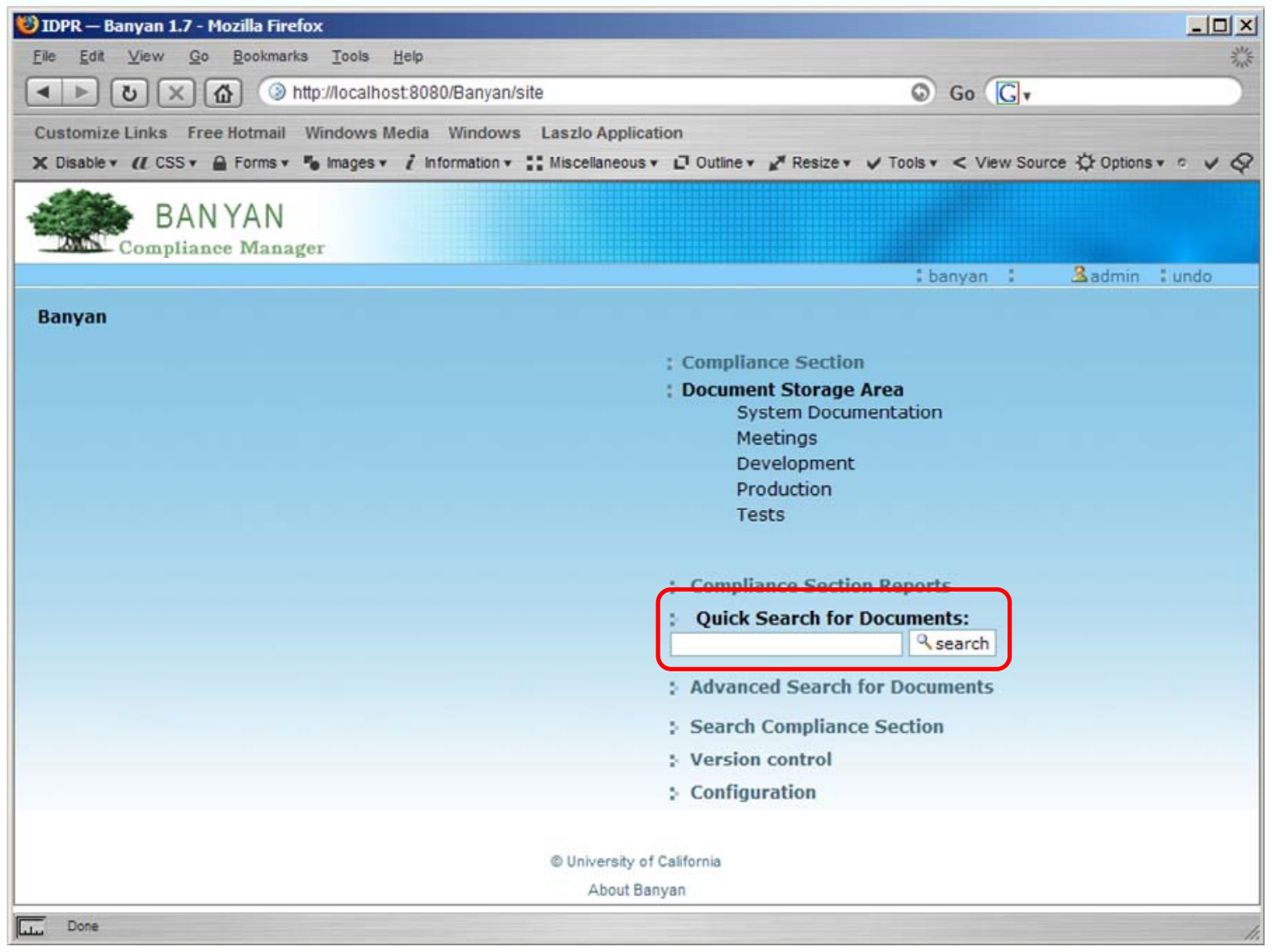

\section{: Quick Search for Documents:}

Rough Q search

Note: multiple copies are due to copies in baselines

\section{BANYAN}

sin Compliance Manager

Search results for DSA

6 items matching your criteria.

Rough Guide [100\%] by admin, 2005-09-03 08:47

W] CM Rough Guide v1.1 [43\%] by admin, 2005-09-03 15:13

W] CM Rough Guide v1.1 [43\%] by admin, 2005-09-03 15:28

W] CM Rough Guide v1.1 [43\%] by admin, 2005-09-03 09:02

TFab Rough Guide v1.0 [42\%] by admin, 2005-09-03 15:2

W. TFab Rouqh Guide v1.0 [42\%] by admin, 2005-09-03 14:01 


\subsection{Searching for Content}

Looking for the word "Password"

\section{: Quick Search for Documents:}

Password Q search

Password is found within documents

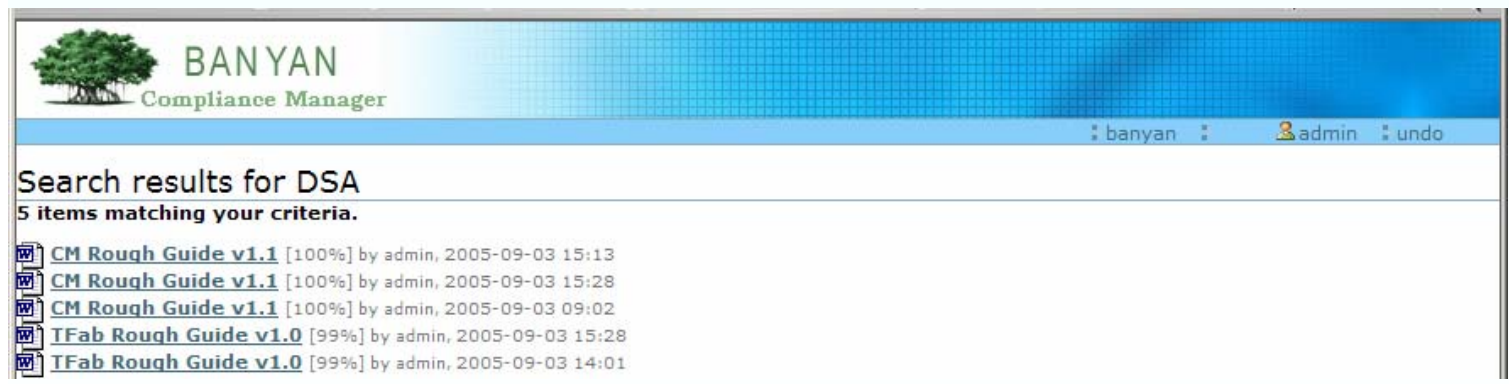

Note, Banyan does not maintain pointers into documents. 


\subsection{Advanced Search for Documents}

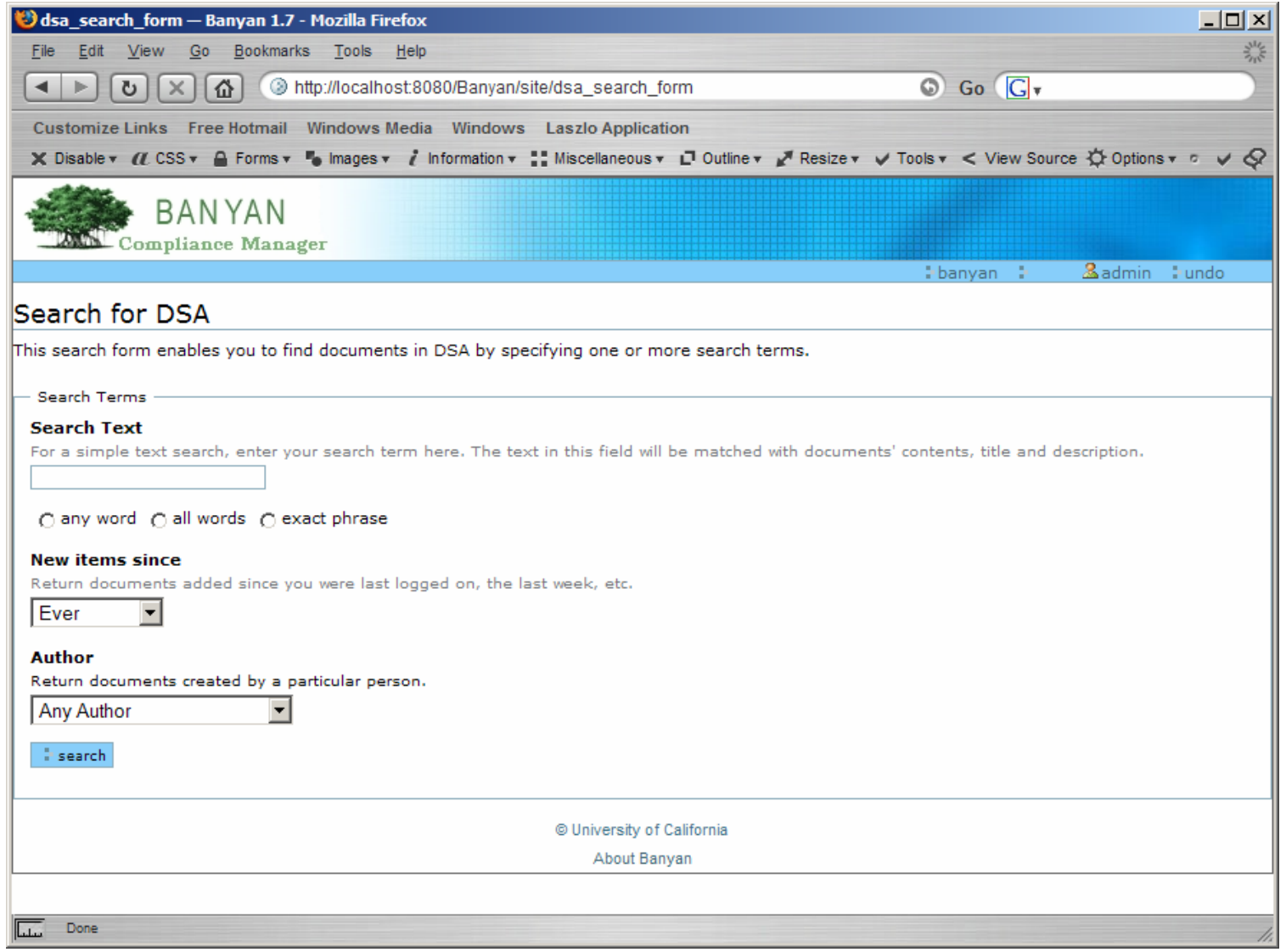




\section{Activity Report}

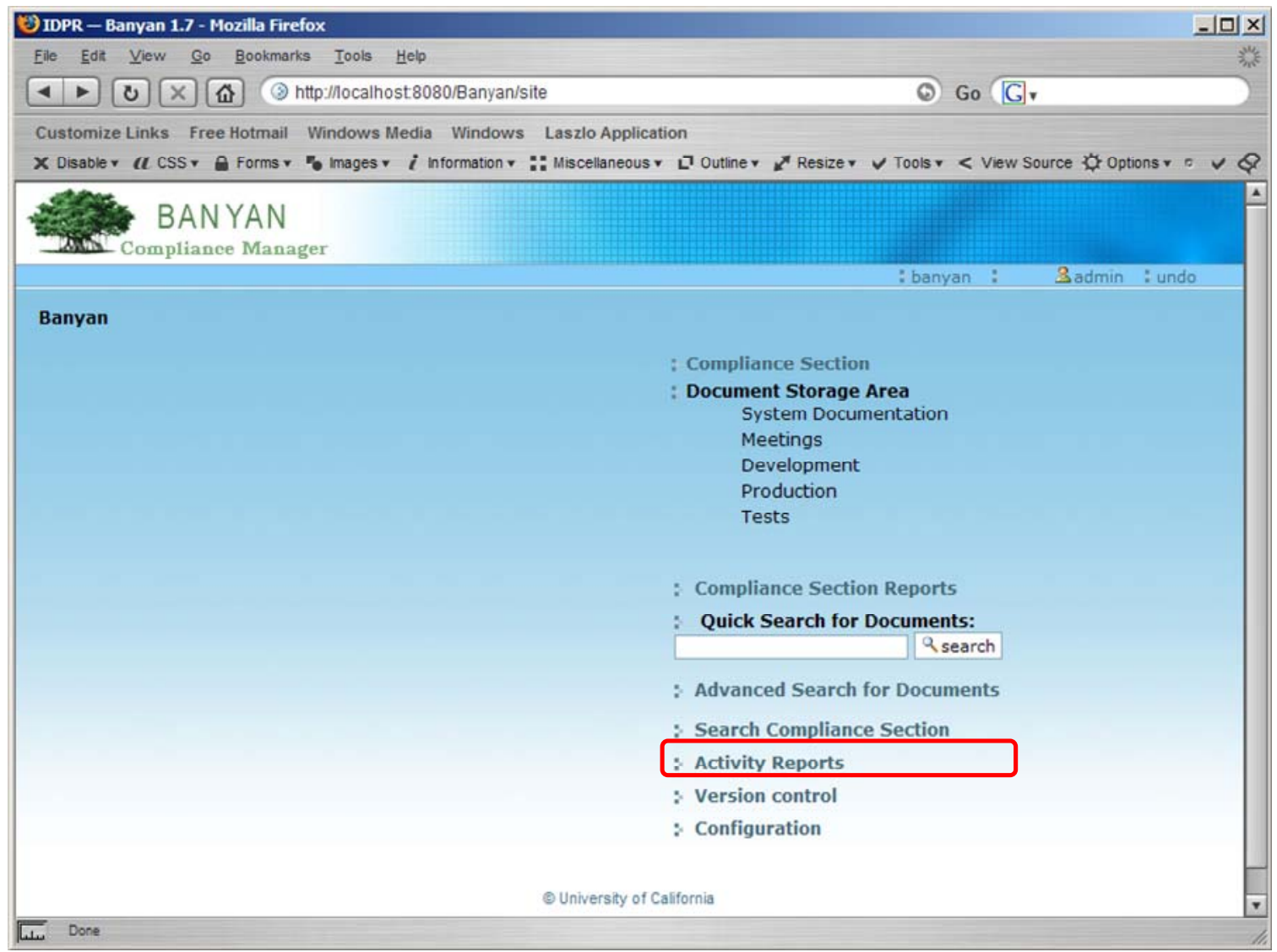

\section{Search criteria}

\section{BANYAN}

Sin Compliance Manager

Search for Compliance Section Elements

Enter query parameters:

Lastweek

: submit query 
activities

admin added CM Rough Guide v1.1 link to Development on 2005/09/03 13:29:23.265 US/Pacific DocumentStorage > Development

admin added at 2005/09/03 14:38:40.953 US/Pacific Baseline One

admin added at 2005/09/03 15:25:11.484 US/Pacific Baseline Two

Banyan_Contributor added at 2005/09/02 15:51:15.159 US/Pacific

admin added at 2005/09/03 08:47:31.812 US/Pacific DocumentStorage > System Documentation > Rough Guide

admin added CM Rough Guide v1.1 at 2005/09/03 08:59:03.593 US/Pacific DocumentStorage > System Documentation > Rough Guide > CM Rough Guide v1.1

admin added TFab Rough Guide v1.0 at 2005/09/03 14:00:54.906 US/Pacific Document5torage > System Documentation > Rough Guide > TFab Rough Guide v1.0 admin added Baseline One at 2005/09/03 15:28:30.343 US/Pacific Baseline One

Banyan_Contributor deleted Fol1 on 2005/09/02 15:52:31,505 US/Pacific

Banyan_Contributor deleted Analyses on 2005/09/02 15:53:02.885 US/Pacific

Banyan_Contributor deleted Surveillance on 2005/09/02 15:53:13.275 US/Pacific

Banyan_Contributor deleted R1 on 2005/09/02 15:53:32.472 US/Pacific

Banyan_Contributor deleted R1.1 on 2005/09/02 15:53:32.672 US/Pacific 


\section{Version Control}

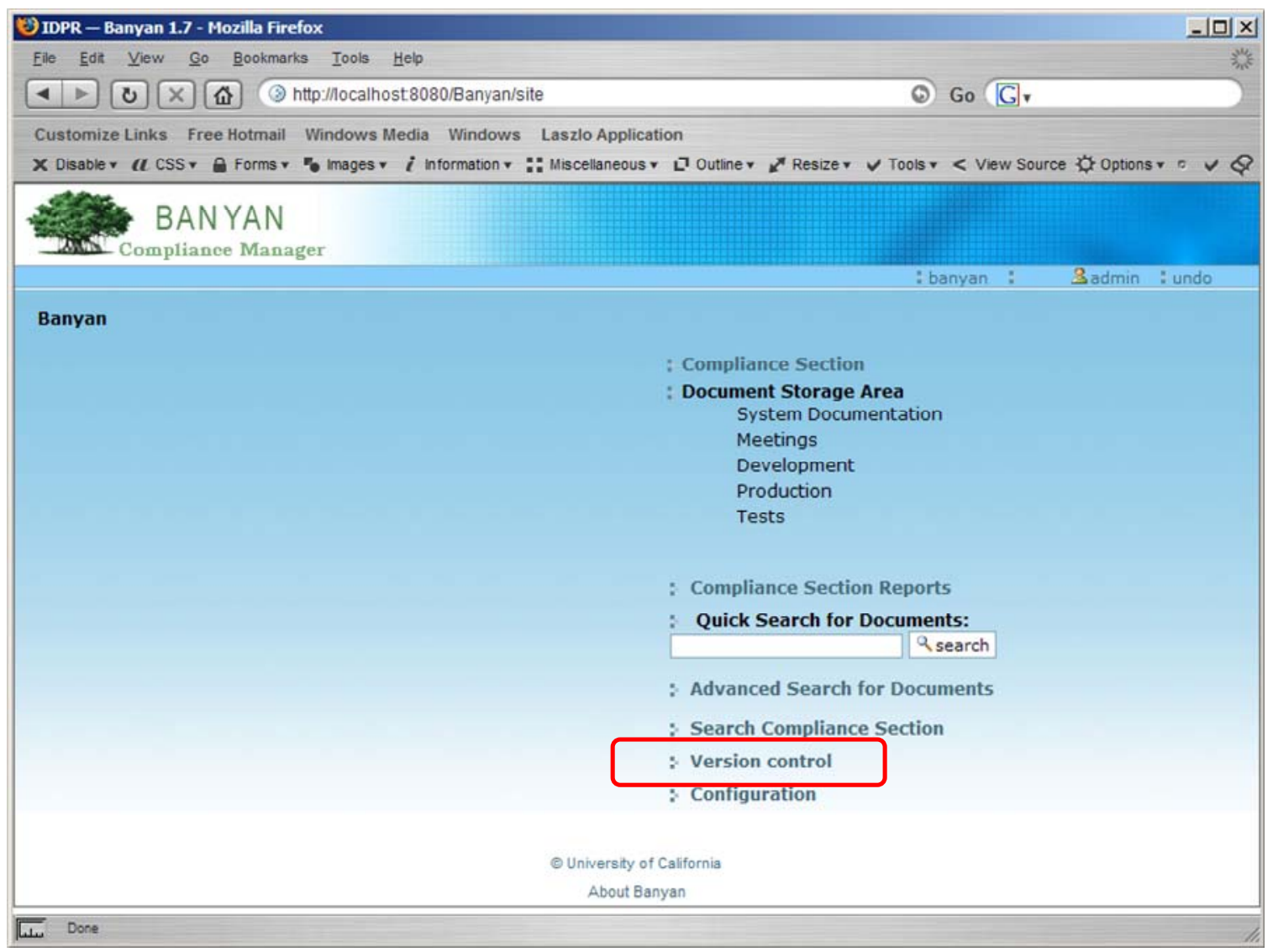

\subsection{Creating a Baseline}

\section{BAN YAN}

sis Compliance Manager

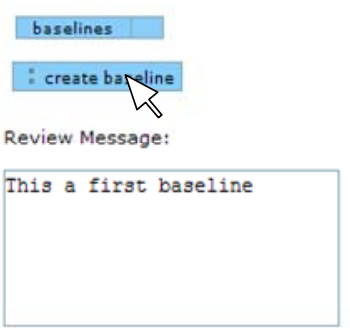




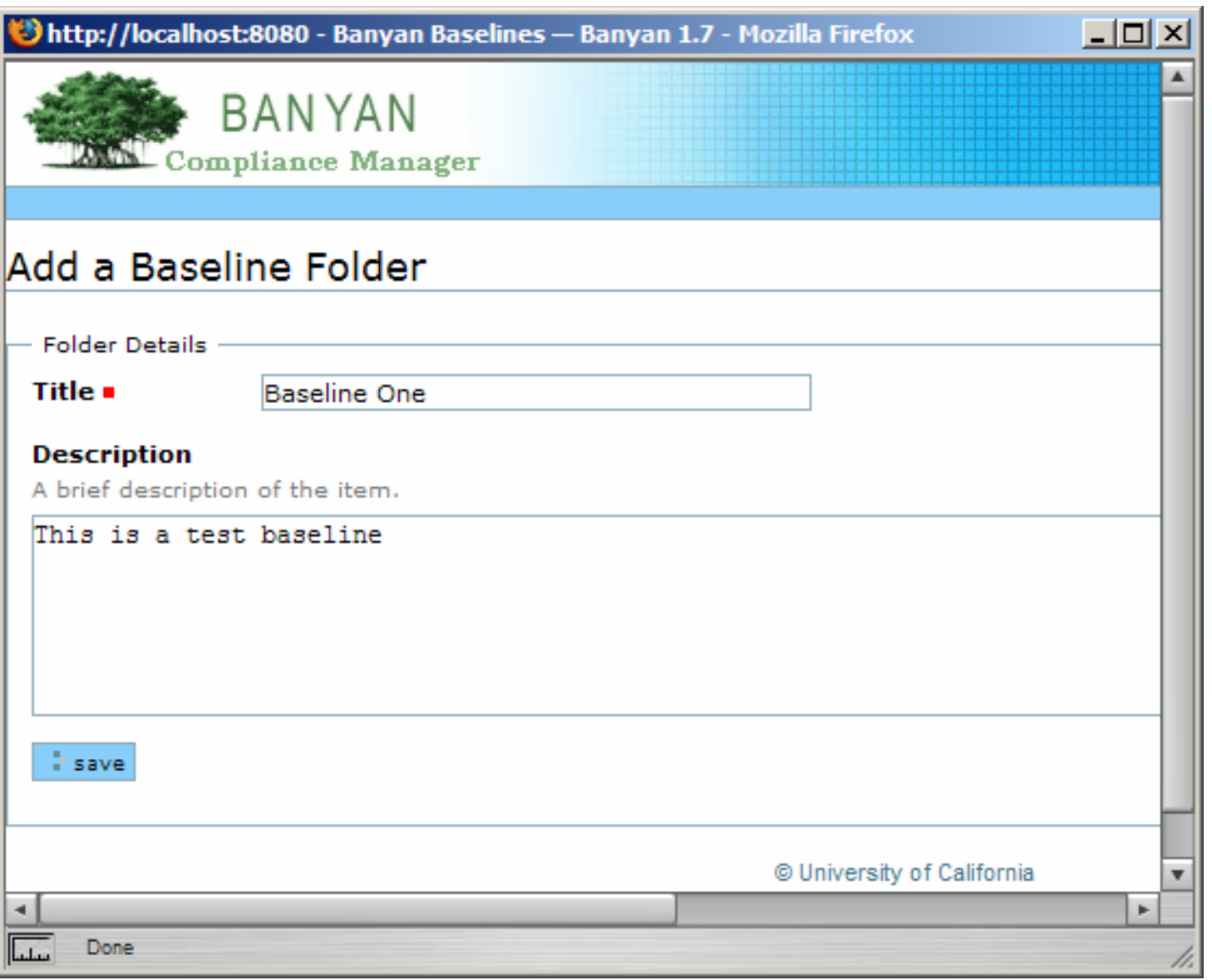

Baseline added

\section{BAN YAN}

compliance Manager

baselines

Baseline One Version: 0 Select

: create baseline

Review Message: 


\subsection{Selecting a Baseline}

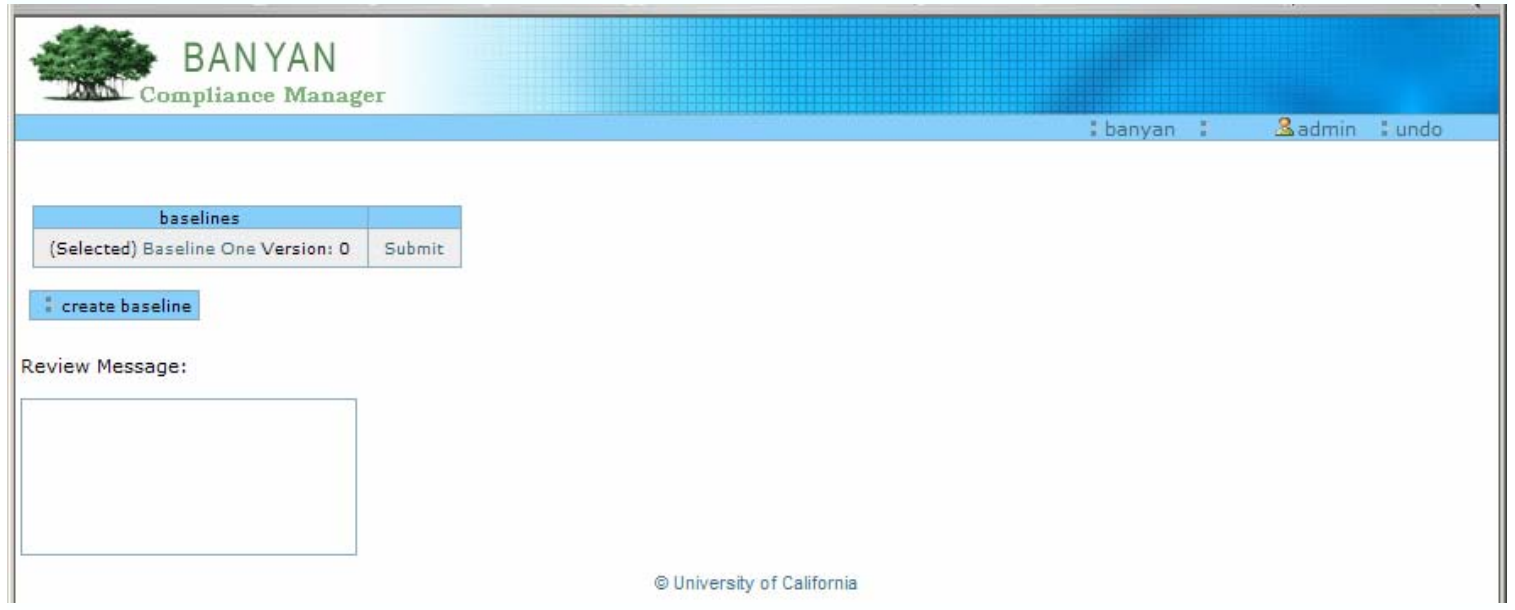

\subsection{Linking a Document to the Baseline}

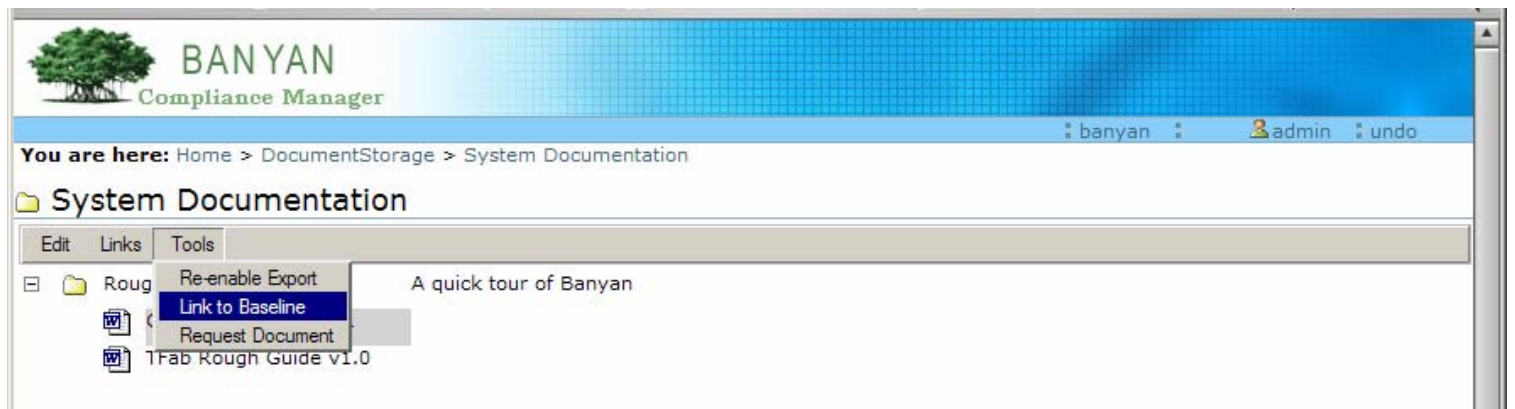

File is now locked for review

You are here: Home > DocumentStorage > System Documentation

$\square$ System Documentation

Add Edit Links Subscribe Tools

$\square \bigcirc$ Rough Guide A quick tour of Banyan

国 CM Rough Guide v1.1 g

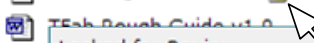

Locked for Review 
5.4 Viewing Proposed Changes to a Baseline

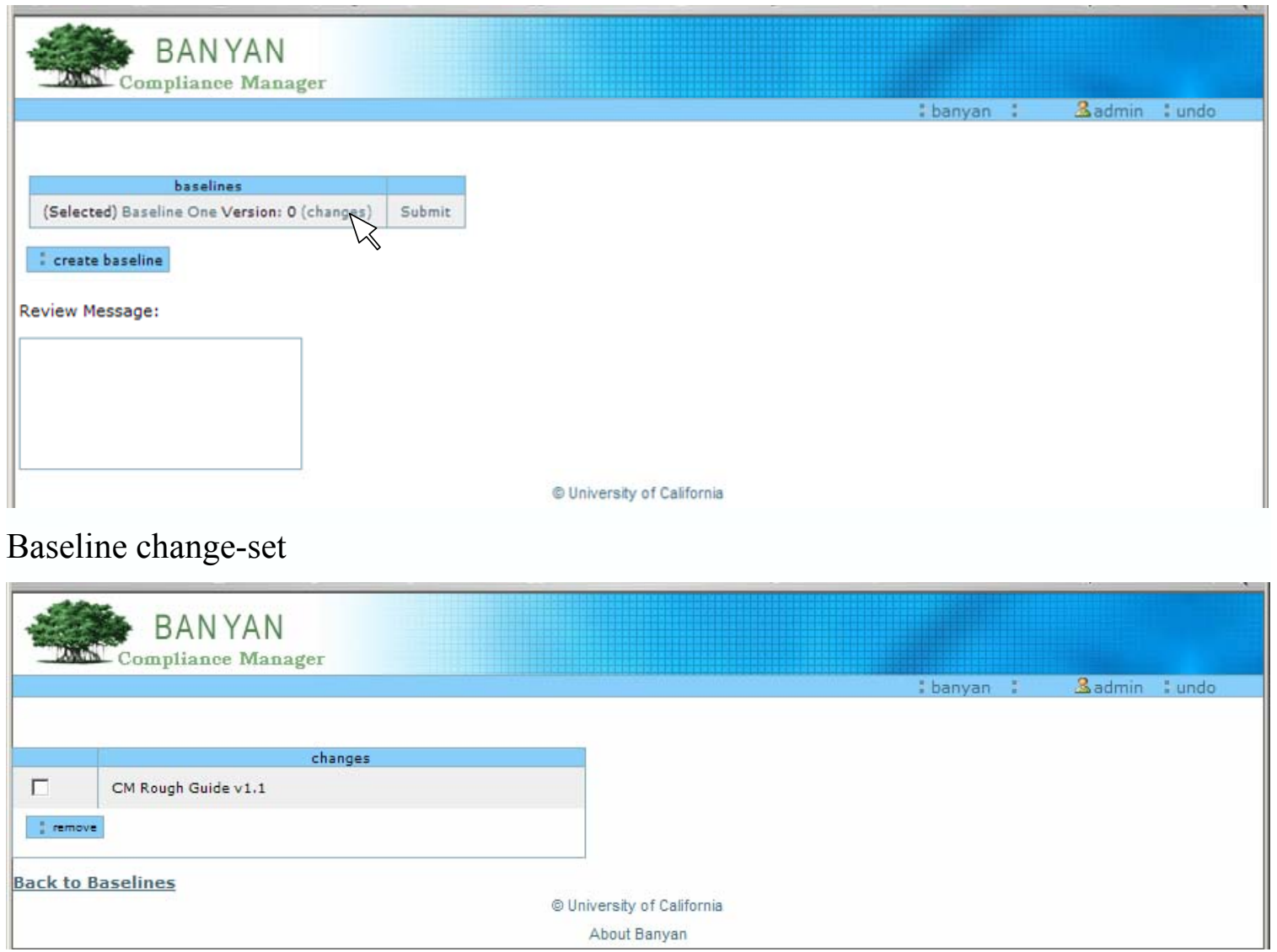

Page 32 


\subsection{Submitting a Baseline}

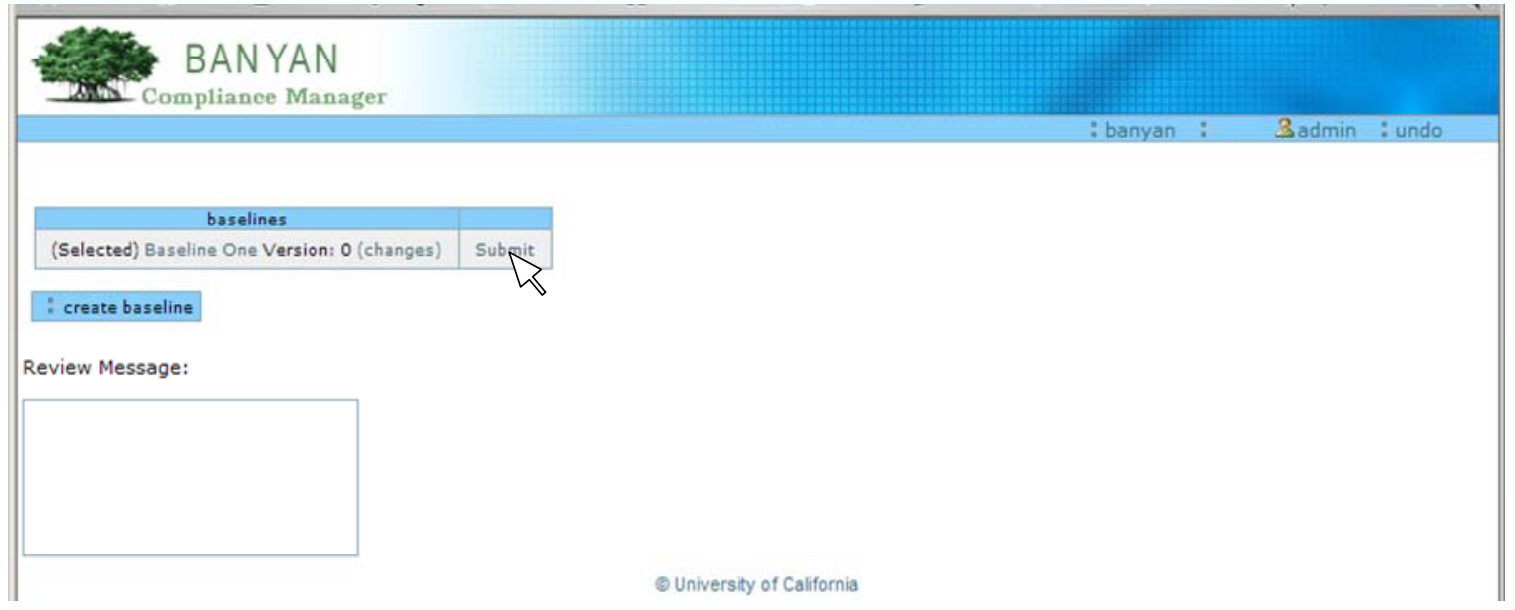

\subsection{Approving a Baseline - Requires Reviewer Role}

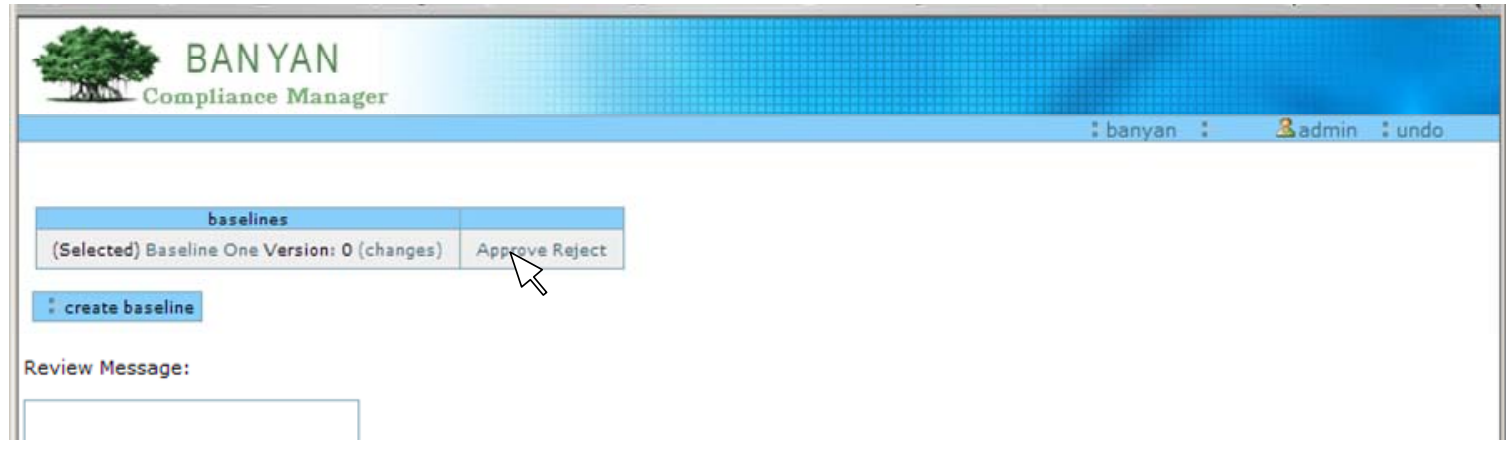

Baseline version is incremented, and the baseline can be resubmitted if changes are made to the new version.

\section{BANYAN}

exs Compliance Manager 


\subsection{Viewing the Contents of a Baseline}

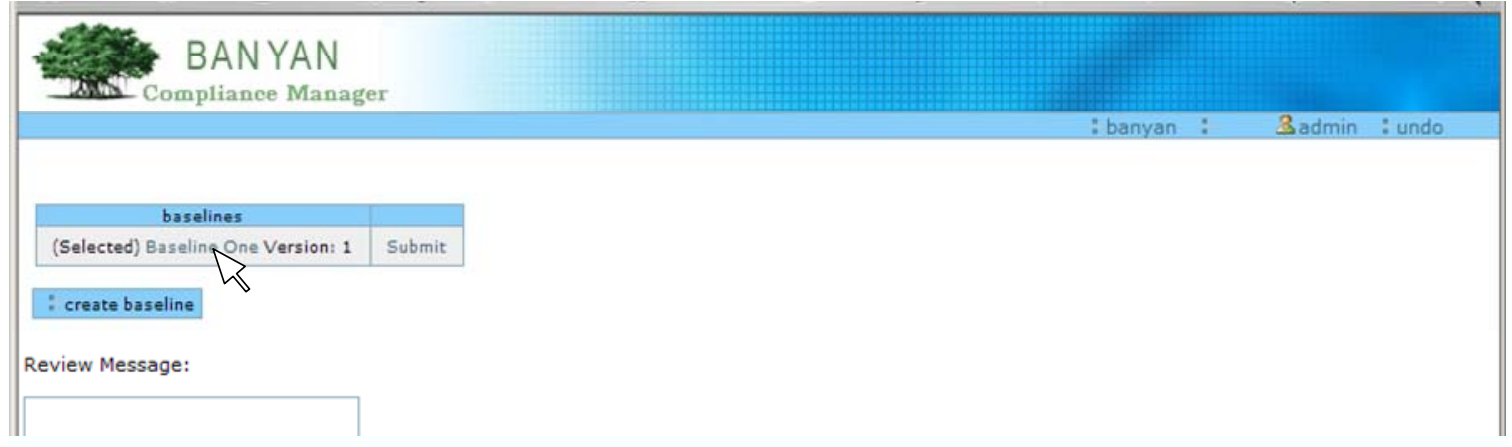

\section{BANYAN}

sim Compliance Manager

You are here: Home > Banyan Baselines > Baseline One

Baseline One

国CM Rough Guide v1.1

\section{(2) University of California}

$\Delta$ hnut Ranuan

When a baseline is approved, documents in the change-set are transferred to the baseline "container" and the original copies have their locks removed.

\section{BANYAN}

sis Compliance Manager

You are here: Home > DocumentStorage > System Documentation

$\square$ System Documentation

Add Edit Links Subscribe Tools

$\square \bigcirc$ Rough Guide A quick tour of Banyan

国 CM Rough Guide v1.1

国 TFab Rough Guide v1.0 


\subsection{Rejecting a Baseline - Requires Reviewer Role}

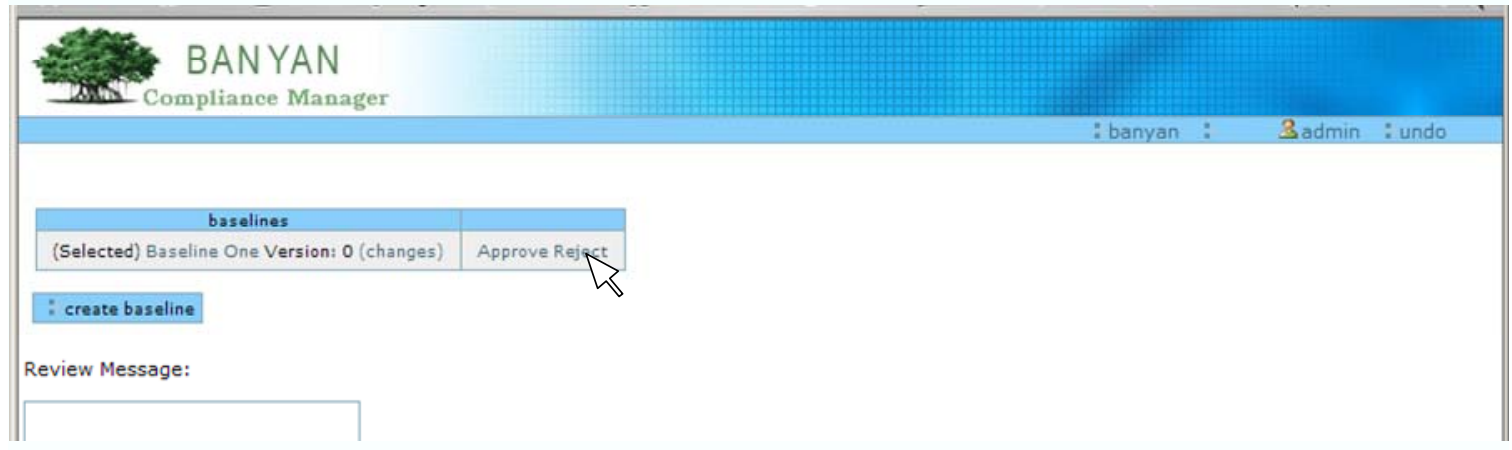

Baseline can be resubmitted

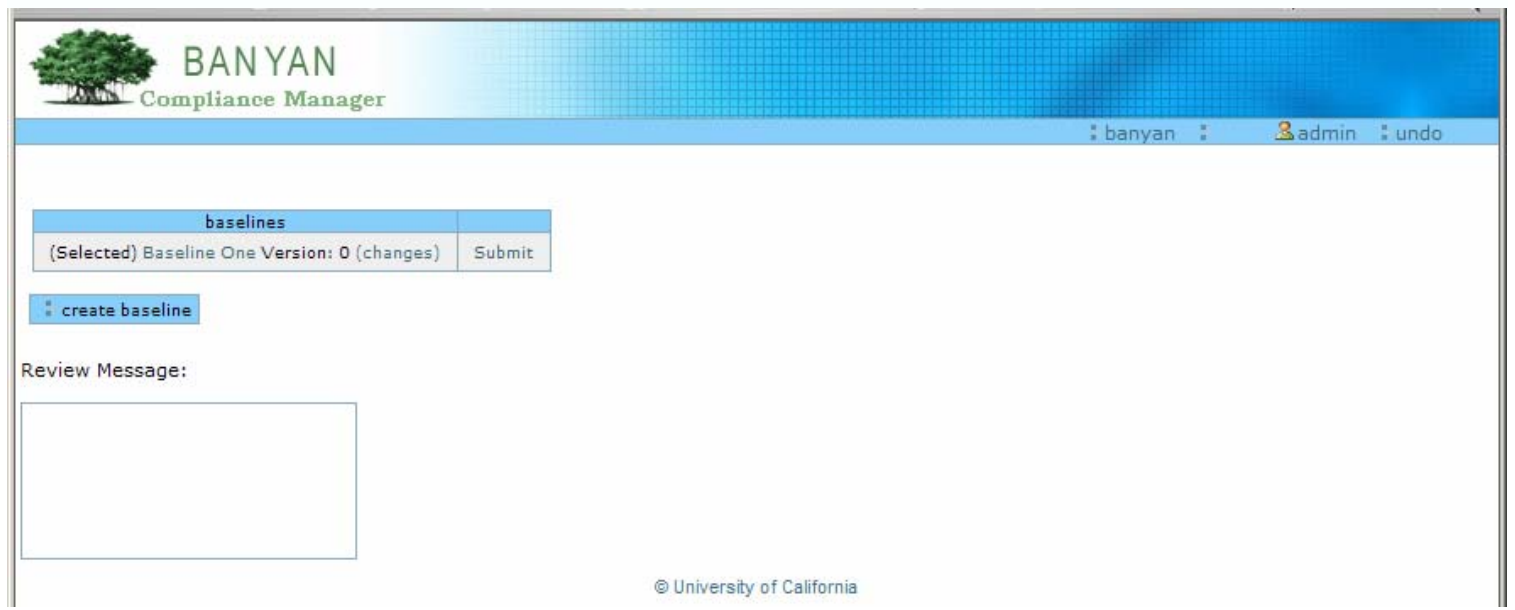

